\title{
Aircraft-based observations and high-resolution simulations of an Icelandic dust storm
}

\author{
A.-M. Blechschmidtt ${ }^{1,2,}$, J. E. Kristjánsson ${ }^{1}$, H. Ólafsson ${ }^{3,4}$, J. F. Burkhart ${ }^{5}$, Ø. Hodnebrog ${ }^{1, * *}$, and P. D. Rosenberg ${ }^{6}$ \\ ${ }^{1}$ Department of Geosciences, University of Oslo, Oslo, Norway \\ ${ }^{2}$ NCAS-Weather, University of Lancaster, Lancaster, UK \\ ${ }^{3}$ Department of Physics, University of Iceland, Reykjavík, Iceland \\ ${ }^{4}$ Geophysical Institute, University of Bergen, Bergen, Norway \\ ${ }^{5}$ Norwegian Institue for Air Research (NILU), Kjeller, Norway \\ ${ }^{6}$ School of Earth and Environment, University of Leeds, Leeds, UK \\ * now at: Institute of Environmental Physics, University of Bremen, Bremen, Germany \\ ** now at: Center for International Climate and Environmental Research-Oslo (CICERO), Oslo, Norway
}

Correspondence to: A.-M. Blechschmidt (anne.blechschmidt@iup.physik.uni-bremen.de)

Received: 18 January 2012 - Published in Atmos. Chem. Phys. Discuss.: 21 March 2012

Revised: 28 September 2012 - Accepted: 23 October 2012 - Published: 16 November 2012

\begin{abstract}
The first aircraft-based observations of an Icelandic dust storm are presented. The measurements were carried out over the ocean near Iceland's south coast in February 2007. This dust event occurred in conjunction with an easterly barrier jet of more than $30 \mathrm{~m} \mathrm{~s}^{-1}$. The aircraft measurements show high particle mass mixing ratios in an area of low wind speeds in the wake of Iceland near the coast, decreasing abruptly towards the jet. Simulations from the Weather Research and Forecasting Model coupled with Chemistry (WRF/Chem) indicate that the measured high mass mixing ratios and observed low visibility inside the wake are due to dust transported from Icelandic sand fields towards the ocean. This is confirmed by meteorological station data. Glacial outwash terrains located near the Mýrdalsjökull glacier are among simulated dust sources. Sea salt aerosols produced by the impact of strong winds on the ocean surface started to dominate as the aircraft flew away from Iceland into the jet. The present results support recent studies which suggest that Icelandic deserts should be considered as important dust sources in global and regional climate models.
\end{abstract}

\section{Introduction}

Iceland has over $20000 \mathrm{~km}^{2}$ of sandy deserts (Arnalds et al., 2001). The sand originates to a large extent from volcanic fly ash and glacial outwash. In particular, volcanic eruptions can cause glacial melting and flooding which leaves behind large amounts of sandy material. Water erosion is the dominant erosion type in southwest Iceland (Arnalds, 2000).

Due to its location inside the North Atlantic storm track, Iceland is frequently affected by synoptic scale cyclones. Together with the effect of Iceland's orography on the airflow, this favors the development of high wind speeds in the vicinity of the sandy areas. The latter can, under dry, snowfree conditions lead to sand storms. Wind erosion in Iceland is very effective in transporting soil material (Ingólfsson, 2008). Maps showing sandy areas, major plume areas and deposition areas in Iceland are given by Arnalds (2010).

Iceland experiences considerable amounts of precipitation throughout the year (Crochet et al., 2007; Rögnvaldsson et al., 2007). However, it is a substantial global dust source with deposition rates comparable to or higher than those found for other areas that are usually considered to contribute to major global dust emissions (Arnalds, 2010; Prospero et al., 2012).

Icelandic dust plumes can be transported over large distances and may affect air quality of the British Isles, continental Europe and the higher latitudes (Ovadnevaite et al., 


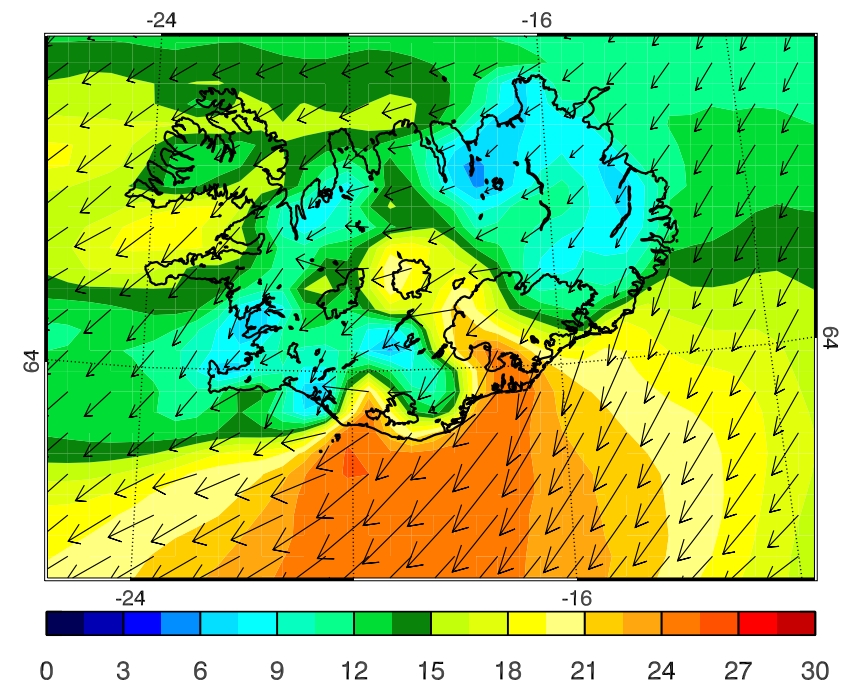

Fig. 1. Wind speed $\left[\mathrm{m} \mathrm{s}^{-1}\right]$ (colored shadings) and wind direction (black arrows) from the WRF/Chem simulation at the lowest model level for G1 on 22 February, 12:00 UTC (see Sect. 4.1 for a description of the model configuration).

2009; Prospero et al., 2008, 2012). Recently, Thorsteinsson et al. (2011) found that dust storms were important contributors to an exceedance of health limit $\mathrm{PM}_{10}$ concentrations measured near Reykjavík during 2007 and 2008. Prospero et al. (2012) investigated measurements from an aerosol sampling site on Heimaey island located near Iceland's south coast between 1997 and 2004. The records revealed that dust was present year-round at concentrations of a few micrograms per cubic meter, but with occasional peaks of up to $1400 \mu \mathrm{g} \mathrm{m}^{-3}$. Using a combination of satellite images and a Lagrangian trajectory model, Prospero et al. (2012) attributed all of their dust measurements to dust storms in southern Iceland.

In addition to studies on Icelandic dust storms, ash transport from Icelandic volcanic eruptions has also been investigated (e.g. Schumann et al., 2011).

We hereby present, to our knowledge, the first aircraftbased study of an Icelandic dust storm. The measurements were carried out during flight B269 of the GFDex (Greenland Flow Distortion experiment; Renfrew et al., 2008) on 22 February 2007, with the UK's BAe-146 Atmospheric Research Aircraft (ARA) operated by the Facility for Airborne Atmospheric Measurements (FAAM). The dust storm occurred during a South Iceland low-level barrier jet event (see Fig. 1 for a map of the wind field). The jet with nearsurface winds of about $30 \mathrm{~m} \mathrm{~s}^{-1}$ was caused by orographic distortion of a northeasterly flow of $10-15 \mathrm{~m} \mathrm{~s}^{-1}$, which was due to a combination of a low pressure area to the south of Iceland and high pressure over Greenland. The flow distortion was particularly pronounced due to a combination of large static stability $(N)$, weak to moderate winds $(U)$ and high mountains over southeastern Iceland $(h)$, as indicated

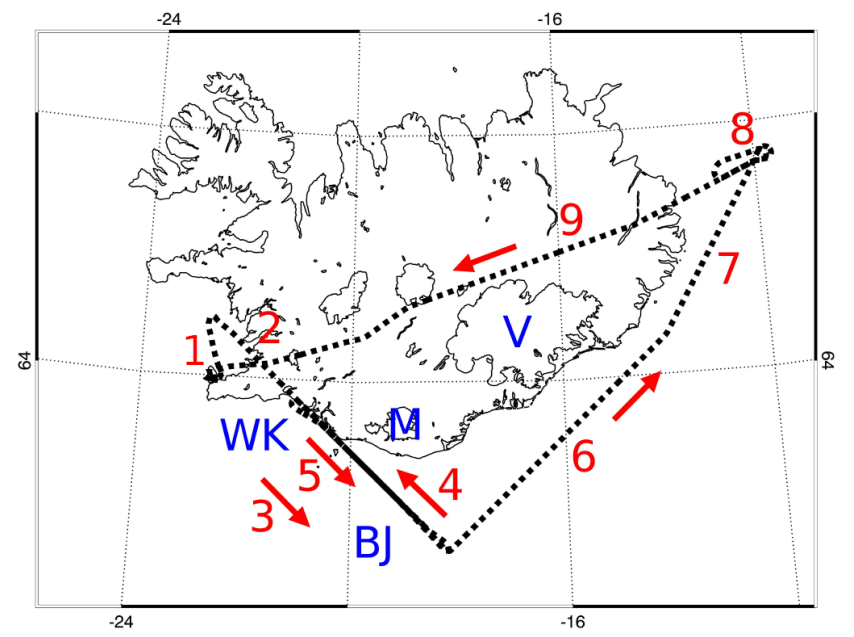

Fig. 2. Aircraft track (dotted line) for flight B269 of the GFDex campaign. The red numbers correspond to different flight legs: (1) take-off, (2) ascending, (3) at $1900 \mathrm{~m}$, (4) at $700 \mathrm{~m},(5)$ at $400 \mathrm{~m}$, (6) ascending, (7-9) at $7600 \mathrm{~m}$. The location of the wake, barrier jet, Mýrdalsjökull glacier and Vatnajökull glacier are indicated by $\mathrm{WK}, \mathrm{BJ}, \mathrm{M}$ and $\mathrm{V}$ respectively. The glaciers are also shown by land contours.

by high values of the inverse Froude number $N h / U$ (Ólafsson et al., 2012). Wind speed maxima occurred downstream of the glaciers Mýrdalsjökull and Vatnajökull (see Fig. 2 for the location of these glaciers). A detailed description of the formation, meteorological conditions and characteristics of the wake and jet is given by Ólafsson et al. (2012).

The primary objective of this flight was to investigate meteorological conditions inside the jet and in the accompanying region of low wind speeds inside Iceland's wake. The dust storm itself was not foreseen by the researchers on the aircraft. Hence, the aircraft was not equipped for measurements of a sand storm. That is why only limited information on aerosols is available. Nonetheless, important measurements of particle mass mixing ratio and particle concentration were carried out. The Weather Research and Forecasting model coupled with Chemistry (WRF/Chem) is used in the present study to better characterise the type of particles sampled by the aircraft. Aircraft measurements indicate that anthropogenic and fire emissions did not contribute to the low visibility observed near Iceland. The WRF/Chem simulations focus on dust and sea salt aerosols which is in agreement with the observations described above. The Lagrangian transport model FLEXPART is used here to identify primary source regions of air masses measured aboard the FAAM flight.

A description of flight characteristics and observed visibilites is given in Sect. 2. Aircraft data and model configurations are described in Sects. 3 and 4, respectively. Simulations and measurements are then compared and discussed in Sect. 5, followed by a brief section on satellite lidar 


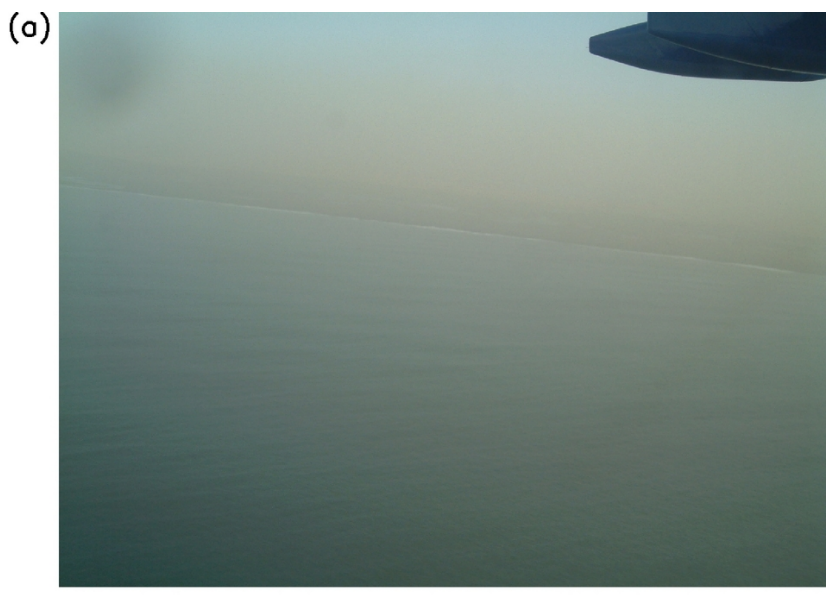

(b)

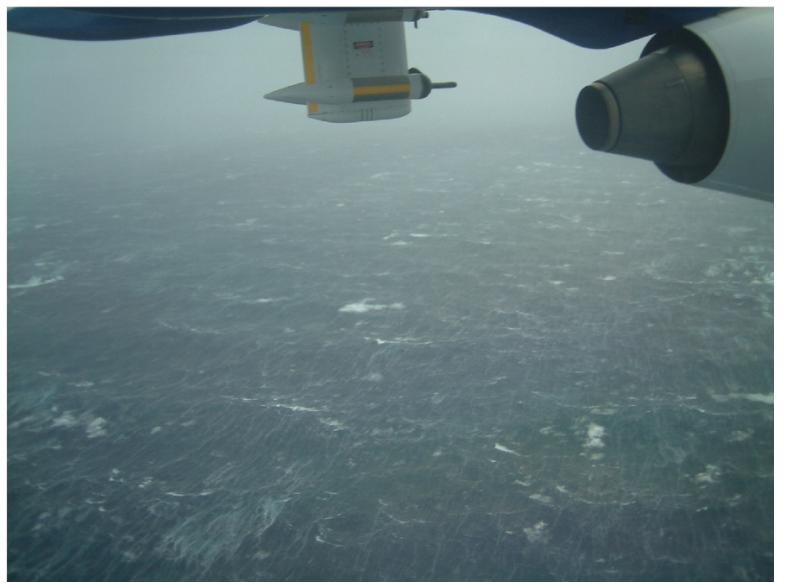

Fig. 3. Photos taken aboard the aircraft showing (a) dust in the wake and (b) the rough sea-surface in the jet.

observations (Sect. 6). Finally, summary and conclusions are given in Sect. 7.

\section{Flight description and observed visibilities}

Figure 2 shows the aircraft track. While the flight started at unlimited visibility at Keflavík, researchers aboard the aircraft were caught by surprise as they flew into very low visibility inside the wake (see Fig. 3a). The visibility decreased sharply towards the coast. The sea-surface inside the wake was almost completely calm and wind speeds reached only a few $\mathrm{m} \mathrm{s}^{-1}$. The view changed completely inside the jet (see Fig. 3b) where strong winds around $30 \mathrm{~m} \mathrm{~s}^{-1}$ roughened the sea surface producing intense sea-spray. The wake and barrier jet region were investigated at three different heights: $1900 \mathrm{~m}$ (leg 3), $700 \mathrm{~m}$ (leg 4) and $400 \mathrm{~m}$ (leg 5). The dust was observed during these flight legs only. The air over central Iceland (leg 9) was clear on the flight day. As can be seen on further pictures taken aboard the aircraft (not shown), the low visibility was more pronounced at the lower elevation

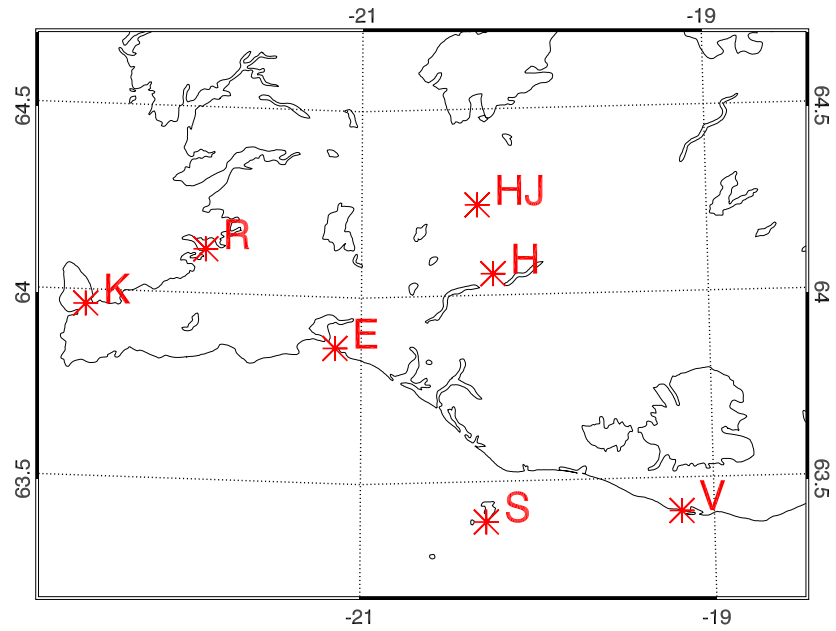

Fig. 4. Locations of manned meteorological stations (red stars) at south-western Iceland. The red letters indicate station names: $(\mathrm{K})$ Keflavíkurflugvöllur, (R) Reykjavík, (E) Eyrarbakki, (HJ) Hjarðarland, (H) Hæll, (S) Stórhöfði and (V) Vatnsskarðshólar.

legs (leg 4 and leg 5) than at leg 3 . In the present paper, only measurements from flight legs 3 to 5 are discussed.

Figure 4 shows locations of meteorological stations at south-western Iceland. Only observations from manned stations are regarded here, since data of present weather and visibility are not available from automated stations. Vatnsskarðshólar (located to the south of the glacier Mýrdalsjökull) and Stórhöfði (at the island of Heimaey) reported widespread dust on the flight day, accompanied by visibilities well below $10 \mathrm{~km}$ in the absence of fog or precipitation. The stations at Reykjavík, Keflavíkurflugvöllur and Hjarðarland reported visibilities of $70 \mathrm{~km}$ or more for the time of the flight. In contrast to this, the visibility at Eyrarbakki showed a strong variability (i.e. $2.4 \mathrm{~km}$ at 09:00 UTC, $>70 \mathrm{~km}$ at 12:00 UTC and 15:00 UTC but only $<0.1 \mathrm{~km}$ at 18:00 UTC). This indicates that Eyrarbakki was probably located somewhere near the border of the dust event. The visibility ranged from $20 \mathrm{~km}$ to $70 \mathrm{~km}$ at Hæll.

\section{Aircraft data}

A suite of instruments were carried on the FAAM aircraft. Only some of them which are related to particles are described here. For a complete list of core instrumentation see Renfrew et al. (2008) and http://www.faam.ac.uk/. The aircraft data were provided by the British Atmospheric Data Centre (BADC) through their web site at http://badc.nerc.ac. uk/home/index.html.

The Passive Cavity Aerosol Spectrometer Probe (PCASP) is an optical particle counter. The instrument measures the intensity of light scattered in the range 35-145 degrees by individual particles as they pass a laser beam. Particles are dried as they are focused into the laser beam. However, large 
measurement errors can occur in cases of particularly moist aerosols, if measurements are carried out inside a cloud or if water droplets shatter on the inlet probe (Taylor et al., 2000).

According to the manufacturer specification, PCASP counts and sizes aerosols in 15 channels between $0.1 \mu \mathrm{m}$ and $3.0 \mu \mathrm{m}$ diameter. These bin boundaries were checked by the manufacturer using polystyrene-latex (PSL) beads and need to be redefined based on optical properties of the sampled aerosol (http://www.faam.ac.uk/). Because the PCASP measures scattered light its measurements are affected by the scattering properties of the particles. The latter are defined by the refractive index, particle shape and particle size. The data shown in this paper have been corrected for these effects by the methods of Rosenberg et al. (2012) using MieLorenz theory assuming spherical particles. Mie-Lorenz theory was chosen based on previous agreement with PCASP measurements and other geometric/optical measurements of non-spherical salt and dust particles (Liu et al., 1992; Rosenberg et al., 2012). In these calculations the real part of the particle refractive index has been assumed to be 1.53 and upper and lower bounds of the complex refractive index have been defined as $0.004 \mathrm{i}$ and $0.002 \mathrm{i}$, respectively. The results provided here are the means from the upper and lower bounds of the complex refractive index with the differences contributing to the uncertainties. These refractive indices have been chosen to bracket the majority of values found for volcanic ash (Bukowiecki et al., 2011; Patterson et al., 1981; Patterson et al., 1983; Schumann et al., 2011). Here, it is assumed that optical properties of Icelandic sand are comparable to volcanic ash as Icelandic dust, which is usually of a relatively dark color, is to a large extent of volcanic origin (Stuart, 1927; Arnalds et al., 2001). However, the chosen refractive index values are also to a good approximation representative of the more common, brighter desert dust type (e.g. McConnell et al., 2010). With all the calibration and refractive index corrections complete, the PCASP size range is $0.133 \mu \mathrm{m} \pm 0.001 \mu \mathrm{m}$ to $4.05 \mu \mathrm{m} \pm 0.2 \mu \mathrm{m}$.

Particle masses have been calculated from the size distributions assuming particle sphericity and a dust density of $2.5 \mathrm{~g} \mathrm{~cm}^{-3}$ for consistency with WRF/Chem. As the first size bin is prone to electrical noise, it was excluded from the results presented here. Particle number concentrations and particle mass mixing ratios shown in the present study are associated with an average error of $10 \%$.

Here, we have applied optical properties of dust and the density of dust only, in order to derive PCASP particle number concentrations and mass mixing ratios for all flight legs. Hence, other particle types have not been accounted for when correcting PCASP data for the scattering properties of the sampled particles. This results in an uncertainty in PCASP measurements presented here for areas dominated by sea salt, which is the case inside the jet. The effect of applying optical properties of dust and the density of dust to PCASP measurements is estimated to lead to total number concentrations/total mass mixing ratios that are by a factor of $1.2 / 2.64$ larger inside the jet compared to PCASP measurements corrected for optical properties and the density of sea salt. However, the effect on total mass mixing ratios is small as the total mass is dominated by dust and not by sea salt. Furthermore, the size range of the PCASP data shown here would be reduced by approximately $2 \mathrm{~nm}$ at the lower end and increased by about $240 \mathrm{~nm}$ at the upper end if optical properties of sea salt instead of optical properties of dust had been applied to the PCASP measurements. In addition, this would lead to a small reduction in particle number concentration at the upper end of the PCASP size range. Overall, the effect of neglecting optical properties and the density of sea salt and other particle types on the PCASP measurements shown in this paper is assumed to be negligible.

The two-dimensional cloud particle imaging probe (2DC) and precipitation particle imaging probe (2DP) measure cloud and precipitation drop size distributions, respectively. Both instruments produce two-dimensional shadow images of particles which pass a laser beam (http://www.eol.ucar. edu/raf/Bulletins/B24/2dProbes.html). The 2DC probe covers diameters from $25 \mu \mathrm{m}$ to $800 \mu \mathrm{m}$, while 2DP covers larger diameters between $200 \mu \mathrm{m}$ and $6400 \mu \mathrm{m}$.

The Fast Forward Scattering Spectrometer Probe (FFSSP) which would cover the gap between the PCASP and 2DC did not operate correctly on the flight and is therefore not regarded here.

\section{Model configurations}

\subsection{WRF/Chem}

The Weather Research and Forecasting (WRF) model is a mesoscale numerical weather prediction and atmospheric simulation system which was developed at the National Center for Atmospheric Research (NCAR) (Skamarock et al., 2008). In WRF/Chem (Grell et al., 2005) an atmospheric chemistry module is fully coupled online with the WRF model.

In the present study we make use of WRF/Chem version 3.1. Our set up includes the Lin et al. (1983) cloud microphysics scheme, and both wet scavenging and cloud chemistry are switched on. The Carbon Bond Mechanism extended version (CBM-Z; Zaveri and Peters, 1999) is used for gas-phase chemistry. The Model for Simulating Aerosol Interactions and Chemistry (MOSAIC; Zaveri et al., 2008) is chosen for simulating aerosols within eight sectional aerosol bins between $0.04 \mu \mathrm{m}$ and $10 \mu \mathrm{m}$ diameter. The vegetation type is defined according to the 24-category land use data from the US Geological Survey (USGS, http://www.usgs. gov/). As will be described in Sect. 5, aircraft measurements of CO concentrations show no signs of anthropogenic pollution or fire emissions, indicating that these pollution types did not contribute to the low visibility observed near Iceland. To simplify our simulations, we hence ran WRF/Chem without 


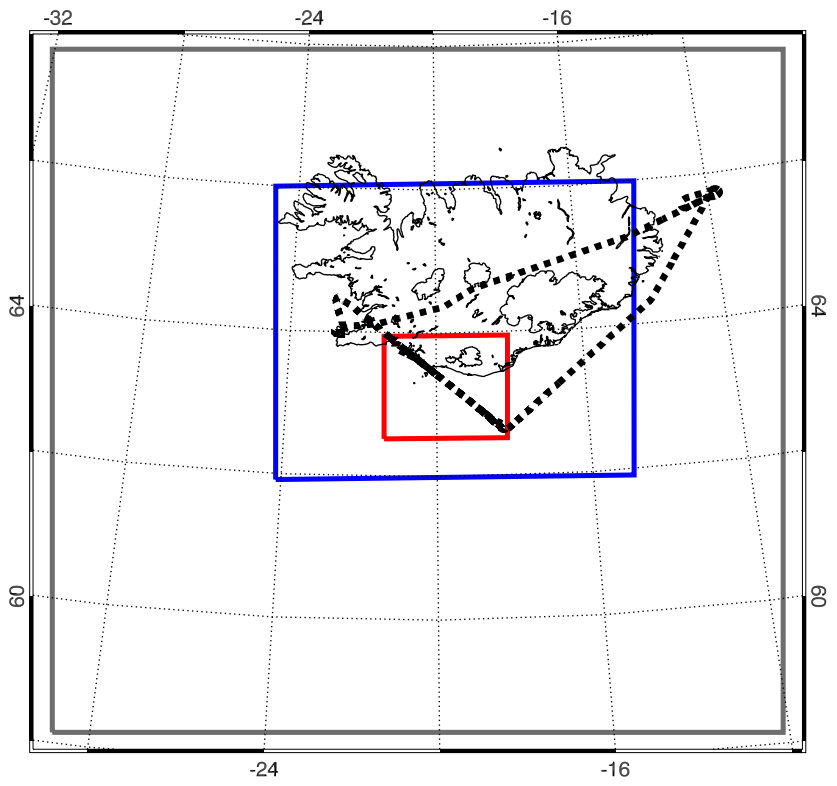

Fig. 5. The WRF/Chem model domains. The grey box shows G1, the blue box G2 and the red box G3. The dotted line corresponds to the aircraft track.

anthropogenic emissions and without fire emissions with the intention to investigate dust and sea salt aerosols (which are produced online by the model) only. For the same reason, idealised vertical profiles as they come with the WRF/Chem software were used as initial and boundary conditions for chemical species. According to Peckham et al. (2010) idealised vertical profiles used in WRF/Chem are based upon results from the NALROM chemistry model. However, the Guenther scheme for biogenic emissions (Guenther et al., 1994) is switched on in our simulations.

WRF/Chem is run with two one-way nested grids to achieve high resolution over the flight domain. NCEP Final Analysis (FNL from GFS) 6-hourly data with $1^{\circ}$ resolution is used for initialising meteorological conditions and as boundary conditions for the outermost domain. The NCEP data was provided by the CISL Research Data Archive through their web site at http://dss.ucar.edu/. The model is started on 22 February 2007 at 00:00 UTC.

Figure 5 shows the model domains. The first grid (G1) has a horizontal grid spacing of $20 \mathrm{~km}$, the second grid (G2) $5 \mathrm{~km}$ and the third grid (G3) a grid spacing of $1 \mathrm{~km}$. The present paper focuses on G3, which is centred on flight legs 3 to 5 to allow comparison with the aircraft measurements.

The original dust routine used in WRF/Chem together with MOSAIC has previously only been applied to regions with very different vegetation characteristics from that of Iceland (e.g. Zhao et al., 1999; Gustafson et al., 2011). The dust routine was changed here, to make WRF/Chem capable of simulating Icelandic dust storms. Furthermore, changes to the sea salt parameterisation were applied. These changes will be described in Sects. 4.1.1 and 4.1.2. In the following, model runs performed with the original dust and sea salt parameterisation are termed OPR, while runs using the modified parameterisation are termed MPR. Most of the results below are based on results from MPR, but some results from OPR are also shown for comparison.

\subsubsection{Dust}

The original dust parameterisation used together with MOSAIC is based on a wind erosion module by Shaw et al. (2008). This module calculates the total mass of wind-blown dust based on vegetation type, soil moisture and wind speed. The size distribution of dust is then retrieved by estimating the dust fraction in different size-bins based on global datasets of soil texture classes.

In OPR dust is only emitted from grid points with grassland, shrubland or savanna as vegetation type. These grid points have a vegetation mask $\alpha$ (which defines the erodable fraction of a grid point) that varies between 0.055 and 0.085 .

In MPR, dust is only emitted from grid points with vegetation type equal to barren or sparsely vegetated, wooded tundra, mixed tundra and bare ground tundra. To our knowledge, only very broad recommendations exist on how to choose the $\alpha$ values for these vegetation types. For example Nickovic et al. (2001) used an $\alpha$ value of 1.0 for deserts and 0.5 for semideserts. On the basis of these broad recommendations, we assumed $\alpha=0.5$ for barren or sparsely vegetated, $\alpha=0.3$ for wooded tundra, $\alpha=0.4$ for mixed tundra and $\alpha=0.5$ for bare ground tundra.

Apart from the dust and sea salt parameterisation, WRF/Chem was set up in exactly the same way for MPR and OPR. However, some rather minor deviations in simulated meteorological parameters such as temperature and wind direction occur between the two simulations. This is due to the fact that some of the parameter choices in the physical parameterisations of WRF/Chem are closely linked to the atmospheric chemistry module (Peckham et al., 2010).

Only the snow cover and ice cover included in the vegetation map from USGS are currently considered in OPR and MPR. Hence, deviations of the actual snow and ice cover for Iceland on 22 February 2007 from USGS 24 category data can lead to errors in simulated dust production. Clouds were present over southern Iceland on the flight day, which precluded detailed satellite-based information on snow and ice cover in this area for that specific day. On the other hand, satellite images from 24 February (not shown) and 25 February (see Fig. 6) are largely cloud free. Furthermore, on other days around 22 February not all parts of Iceland were hidden by clouds. Combining the snow cover information from 24 to 25 February with the more fragmentary information deduced from the other satellite images on and around 22 February, we conclude that the satellite image from 25 February (Fig. 6) is to a good approximation representative of the 


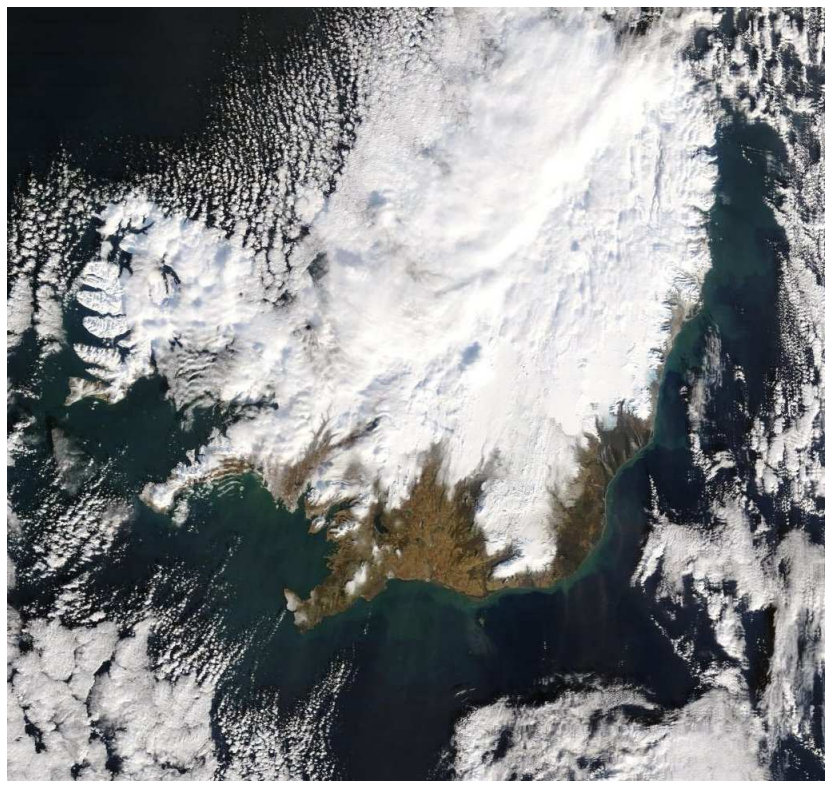

Fig. 6. MODIS Terra true-color satellite image from 25 February 2007 at 13:20 UTC (image courtesy of the NASA/GSFC Rapid Response system, http://lance.nasa.gov/imagery/rapid-response/).

snow cover on the flight day. Note that Fig. 6 is also representative of snow cover on the day of the CALIPSO observation which will be described in Sect. 6 .

Figure 6 reveals that large parts of South and West Iceland were indeed snow and ice free and that these areas are reasonably represented by the USGS data set. However, there is a significant underestimation of the snow and ice cover for G1 and $\mathrm{G} 2$ leading to errors in simulated dust production in those regions. Moreover, an overestimation of snow or ice cover occurs to the south-west of the Vatnajökull glacier in the outer model domains. Regarding G3, the satellite images indicate that snow and ice present to the north of Mýrdalsjökull is not included in our simulations while there is an overestimation of snow and ice to the southeast of this glacier. Since the highest wind speeds occur downstream of the glacier (see Fig. 8) it is assumed here that deviations from the actual snow and ice cover for G3 do not affect the dust simulations significantly. However, the extent to which errors in dust production in G1 and G2 influence the dust simulations for G3 presented here remains uncertain as dust fluxes are not part of the WRF/Chem model output.

\subsubsection{Sea salt}

In OPR sea salt is parameterised according to Gong and Barrie (1997). That study makes use of Eq. (6) from Monahan et al. (1986) to express the rate of sea salt droplet generation at the sea surface. The equation shows a monotonic increase with decreasing particle size for diameters smaller than $0.2 \mu \mathrm{m}$. In contrast to this, measurements and laboratory experiments (e.g. O'Dowd and Smith, 1993; Nilsson et al.,
2001; Mårtensson et al., 2003) have shown that there is a major contribution of particles in the submicrometer range with a maximum around $0.1 \mu \mathrm{m}$ diameter and decreasing values towards smaller sizes.

We therefore changed the sea salt parameterisation in MPR to that of Gong (2003) who introduced a modified version of the equation by Monahan et al. (1986) to reduce sea salt number flux density below $0.1 \mu \mathrm{m}$ and additionally increase the flux at $0.1 \mu \mathrm{m}$. In MPR a $\theta$ value of 11 is used for Gong's equation. According to Nilsson et al. (2007) this results in the best agreement between the simulated sea salt flux and sea salt measurements carried out at Mace Head (Ireland) between May and September 2002 for diameters between $0.1 \mu \mathrm{m}$ and $1.1 \mu \mathrm{m}$. Note that the measurements by Nilsson et al. (2007) were carried out at average water temperatures of $12^{\circ} \mathrm{C}$. This implies that some errors for the simulated sea salt flux may occur due to somewhat lower water temperatures at simulation time. Laboratory simulations by Mårtensson et al. (2003) have shown that when water temperatures increase, sea salt number concentrations decrease for diameters smaller than $0.07 \mu \mathrm{m}$ and increase for diameters larger than $0.35 \mu \mathrm{m}$. Inspection of satellite images available at http://www.remss.com shows that the ocean had a sea surface temperature of about $8^{\circ} \mathrm{C}$ on the flight day.

\subsection{Flexpart}

The Lagrangian Particle Dispersion Model (LPDM) FLEXPART has been used to examine source regions for numerous aircraft, station, and ship-based studies (Stohl et al., 2005; Stohl, 2006; Warneke et al., 2009; Gilman et al., 2010; Hirdman et al., 2010). The model provides source information for a measurement point by examining clusters of so-called tracer particles transported in the atmosphere. Mean winds from the European Centre for Medium-Range Weather Forecasts (ECMWF, 2002) model output are included in the simulations along with parameterisations to account for turbulence and convective transport. These processes, which are not included in standard trajectory models, are important for a realistic simulation of the transport of trace substances (Stohl, 2002).

FLEXPART was run backward in time from the aircraft measurement location using operational analyses from ECMWF with $0.5 \times 0.5^{\circ}$ resolution for FAAM flight B269. To provide releases along the flight track, 50000 particles were released with any horizontal movement of the aircraft of $0.19^{\circ}$ latitude or longitude, and a vertical change in pressure coordinates of $10 \mathrm{hPa}$.

The model simulation was run with a generic aerosol tracer. The aerosol tracer was removed by wet and dry deposition processes (Stohl et al., 2005). In addition, air parcels were removed from the simulation after a life-time of 20 days. Anthropogenic emissions were initialised from the updated EDGAR 3.2 emissions inventory for the year 2000 (Olivier et al., 2001). 

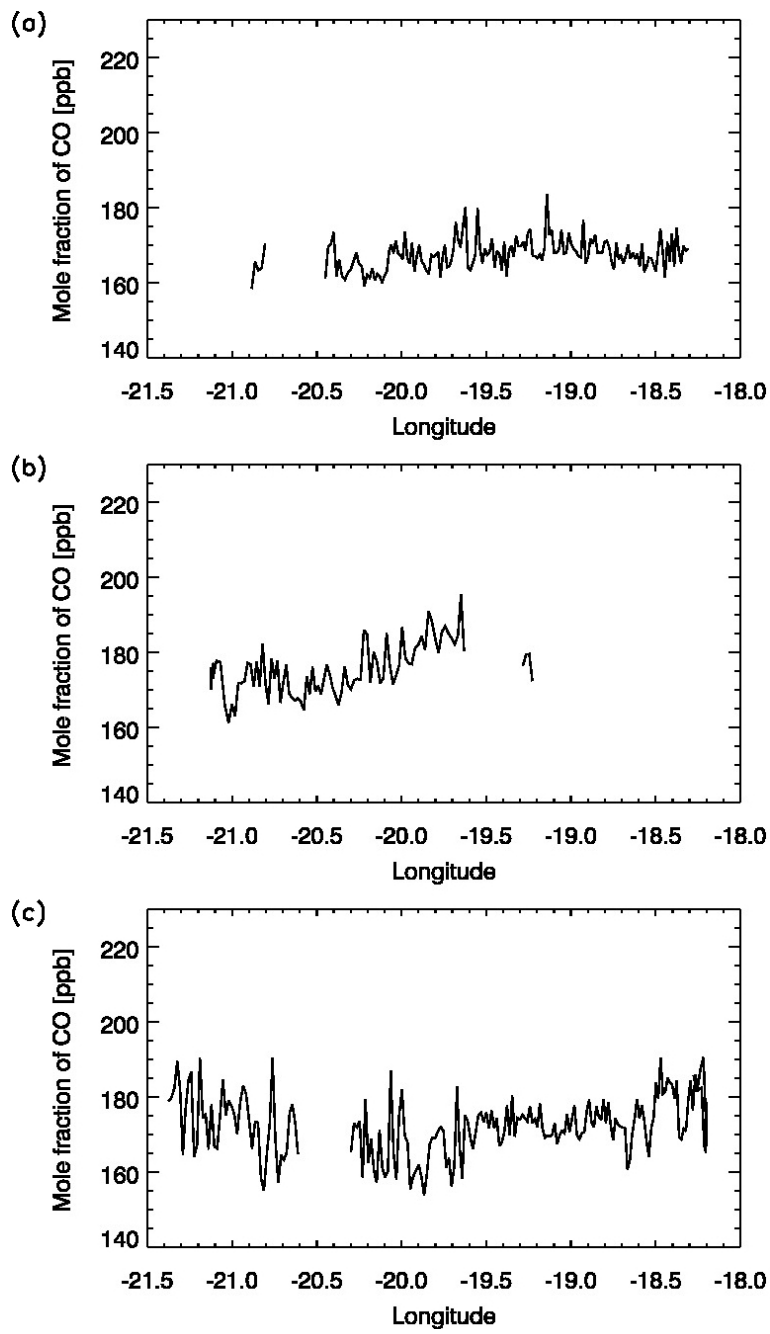

Fig. 7. Aircraft measurements of mole fraction of $\mathrm{CO}$ [ppb] from the AL5002 Carbon Monoxide instrument for (a) $400 \mathrm{~m}$ height, (b) $700 \mathrm{~m}$ height and (c) $1900 \mathrm{~m}$ height. The values shown are $10 \mathrm{sec}-$ ond averages.

We present the results showing a footprint "Potential Emission Sensitivity" (PES) which represents the sensitivity of the measured air mass to global emissions backward in time for the lowest $100 \mathrm{~m}$ above the surface. Since most emissions occur at the surface, the footprint PES is of particular importance (Jonson, 2010).

\section{Results}

\subsection{Aircraft measurements and WRF/Chem simulations}

Measurements from 2DC and 2DP (not shown) indicate that some cloud and/or precipitation particles were present during flight legs 4 and 5, the vast majority of them inside the jet. However, only very low concentrations of less than $1201^{-1}$

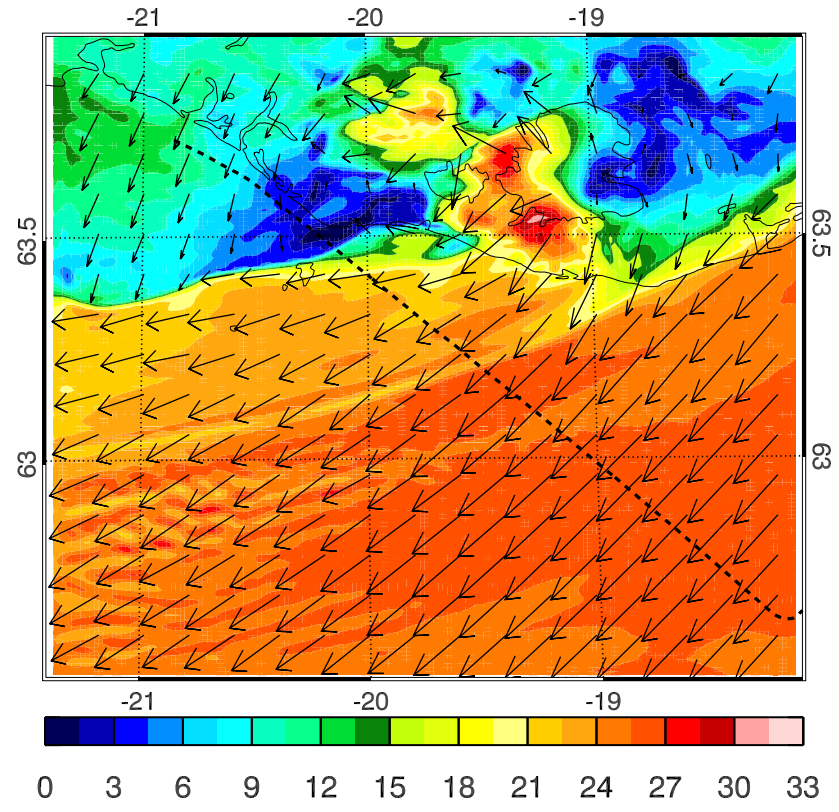

Fig. 8. Simulated wind speed $\left[\mathrm{m} \mathrm{s}^{-1}\right]$ (colored shadings) and wind direction (black arrows) at the lowest model level for G3 on 22 February, 12:00 UTC. The dotted line corresponds to leg $5(400 \mathrm{~m}$ height) of the aircraft track. The thin black contours represent land contours.

for 2DC and not more than $0.13 \mathrm{l}^{-1}$ for 2DP were measured. Neither instrument detected any particles during leg 3 . We deduce that errors in PCASP measurements due to clouds and precipitation are unlikely. The 2DC and 2DP measurements are mainly in agreement with locations of precipitation and clouds simulated by WRF/Chem (not shown), although some precipitation (graupel and snow) is simulated for leg 3 which is not present in the measurements.

Figure 7 shows mole fraction of $\mathrm{CO}$ measured at different heights by the aircraft. These 10 second averaged values range broadly from $150 \mathrm{ppb}$ to $190 \mathrm{ppb}$, indicating that measurements were carried out in clean or only moderately polluted tropospheric air away from urban areas. Typical values in clean tropospheric air range from $40 \mathrm{ppb}$ to $200 \mathrm{ppb}$ (Seinfeld and Pandis, 2006), while typical values in urban areas away from freeways reach $2 \mathrm{ppm}$ to $10 \mathrm{ppm}$ (Jacobson, 1999). The CO measurements are not correlated with PCASP particle number and mass mixing ratios which will be described below. The measurements hence show that anthropogenic pollution or fire emissions did not contribute to the low visibility observed near Iceland's south coast.

Maps of the simulated wind field and simulated mass mixing ratios at the lowest model level are shown in Figs. 8 and 9 , respectively. Basically, high dust mass mixing ratios are found inside the wake while values decrease towards the jet. The opposite is true for sea salt mass mixing ratio. Local wind speed maxima occur around Mýrdalsjökull, probably due to orographic effects. Large amounts of dust are present 


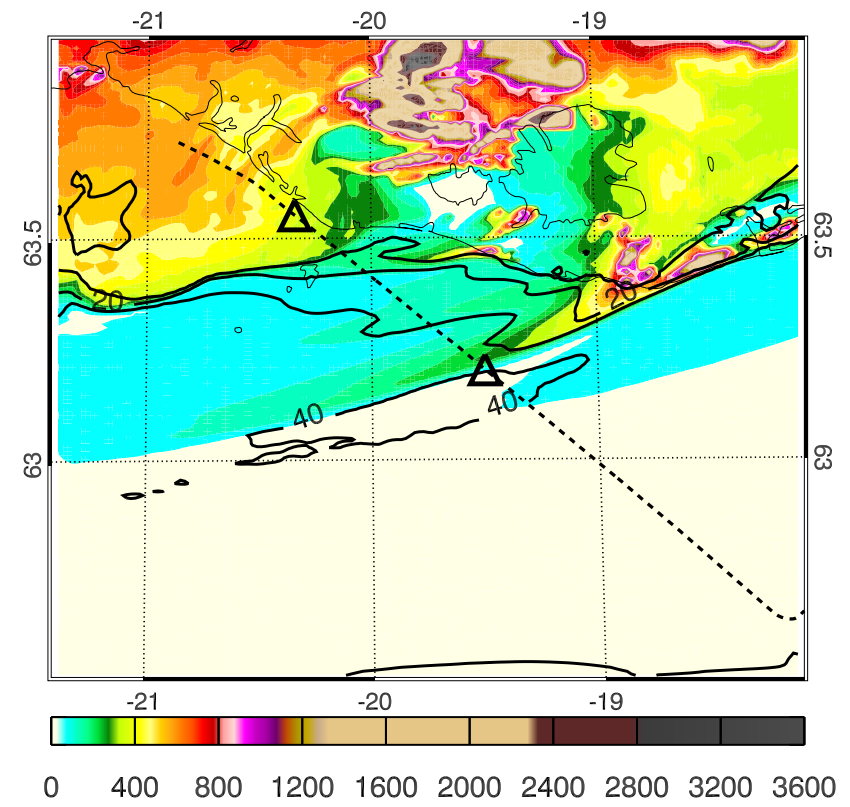

Fig. 9. As in Fig. 8 but for dust mass mixing ratio $\left[\mu \mathrm{g} \mathrm{kg}^{-1}\right]$ (colored shadings) and sea salt mass mixing ratio $\left[\mu \mathrm{g} \mathrm{kg}^{-1}\right]$ (thick black contours) for particle diameters between $0.04 \mu \mathrm{m}$ and $10 \mu \mathrm{m}$. Locations of the two mass mixing ratio peaks measured at $400 \mathrm{~m}$ (see Fig. 12) are indicated by black triangles.

to the north-west and south-east of the glacier. According to the Agricultural Research Institute and Soil Conservation Service of Iceland (http://www.rala.is/desert/), these areas suffer from considerable to extremely severe erosion.

Note that some of the dust shown in Fig. 9 for G3 may have been transported there from the outer domains (i.e. from the north-east, as north-easterly winds prevailed on the flight day). However, comparing the wind field shown in Fig. 8 with the vegetation map for G3 (not shown) and looking at the time evolution of dust mass mixing ratios for all three model domains reveals that large amounts of dust are most likely produced within G3 directly. This is especially true for the dust maxima around Mýrdalsjökull.

Two manned meteorological stations, Vatnsskarðshólar and Stórhöfði (see Fig. 4 for locations of these stations), reported poor visibility and dust on the flight day, confirming the simulations. Overall, the location of the wind speed maxima around Mýrdalsjökull relative to dust maxima indicates that orographic effects may have contributed to the formation of the dust storm. This is in agreement with Ólafsson (2005) who pointed out that local orographic effects may be important for dust storms in Iceland.

Measurements and simulations of wind speed and wind direction at all flight legs are shown in Fig. 10. These two meteorological parameters are crucial for simulating dust and sea salt aerosols. Wind speed determines the amount of dust and sea salt which is brought up into the air, while wind direction determines the location to which aerosols are transported.
Apart from some differences in wind speed at $1900 \mathrm{~m}$, there is a very good agreement between the aircraft and the model. The strong increase in wind speed from the wake towards the jet measured at $400 \mathrm{~m}$ and $700 \mathrm{~m}$ height is very well captured by the model.

Corresponding results for temperature and specific humidity are shown in Fig. 11. Overall the model agrees well with the aircraft. Both, observations and simulations show that temperature decreases with height. However, the static stability appears to be weaker between $400 \mathrm{~m}$ and $700 \mathrm{~m}$ in the measurements than in the simulations while the opposite is the case between $700 \mathrm{~m}$ and $1900 \mathrm{~m}$ height.

Particle mass mixing ratios and particle number concentrations are given in Fig. 12. Note that the simulations are only plotted for the PCASP size range from $0.133 \mu \mathrm{m}$ to $4.05 \mu \mathrm{m}$. The errors associated with the PCASP size range (see Sect. 3) lead to an average uncertainty of $4 \% / 1.5 \%$ for simulated particle mass mixing ratios/simulated particle number concentrations.

The measurements show two maxima at $400 \mathrm{~m}$ height, one around $20.35^{\circ} \mathrm{W}$ longitude (inside the wake) and one near $19.5^{\circ} \mathrm{W}$ longitude (inside the jet). The former one coincides with a sharp change in wind speed and wind direction (see Fig. 10). Convergence of air masses may be an explanation for the formation of this peak. The results shown in Fig. 9 (note that the location of the two measured mass mixing ratio peaks is given by the black triangles) indicate that dust transported from sand fields located to the south-east of the Mýrdalsjökull glacier towards the ocean contribute to the latter peak, while dust sources to the west of this glacier contribute to the former peak. Figure 12 shows that the measured particle mass mixing ratios and particle number concentrations generally decrease as the aircraft flies away from Iceland towards the jet.

At $400 \mathrm{~m}$ height, simulations for the sum of all aerosol types represented by the model (red line in Fig. 12) catch the shape of measured mass mixing ratios and particle concentrations well. However, the location of the western peak is simulated further north-westwards than the corresponding measured peak. WRF/Chem strongly underestimates the magnitude of mass mixing ratios for longitudes to the west of $19.5^{\circ} \mathrm{W}$. In contrast to this, the magnitude of particle number concentrations is much better captured by the model. There is a tendency for WRF/Chem to overestimate dust number concentrations inside the wake and to underestimate sea salt number concentrations inside the jet.

Comparing simulations at $400 \mathrm{~m}$ height for dust and sea salt with the sum of all aerosol types represented by the model indicates that the high particle mixing ratios and particle number concentrations measured inside the wake and in the north-western part of the jet west of $19.5^{\circ} \mathrm{W}$ are due to dust. Sea salt aerosols become the dominating aerosol type as the aircraft flies away from Iceland towards the jet. This is in agreement with airmass source regions identified by Flexpart which will be described in Sect. 5.2. 
(a)

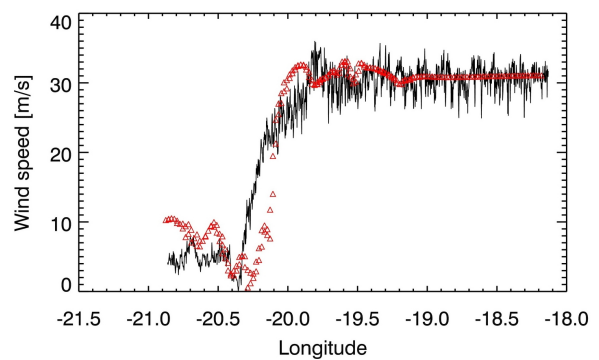

(b)

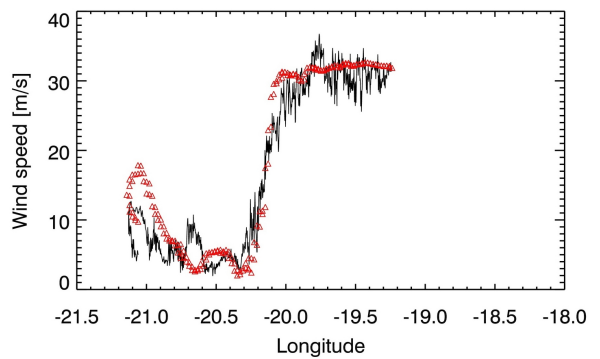

(c)

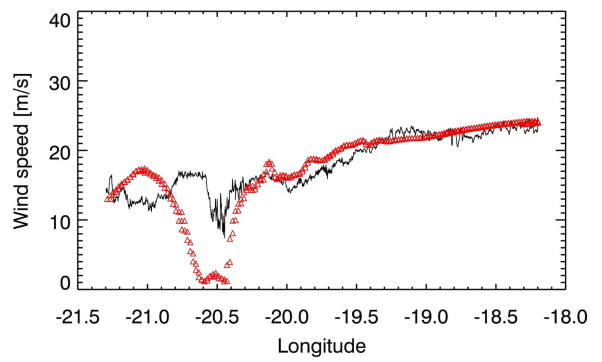

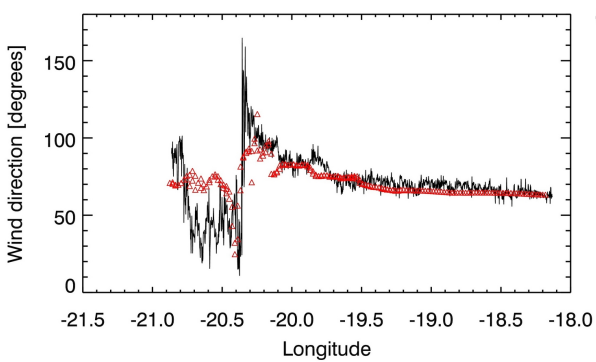
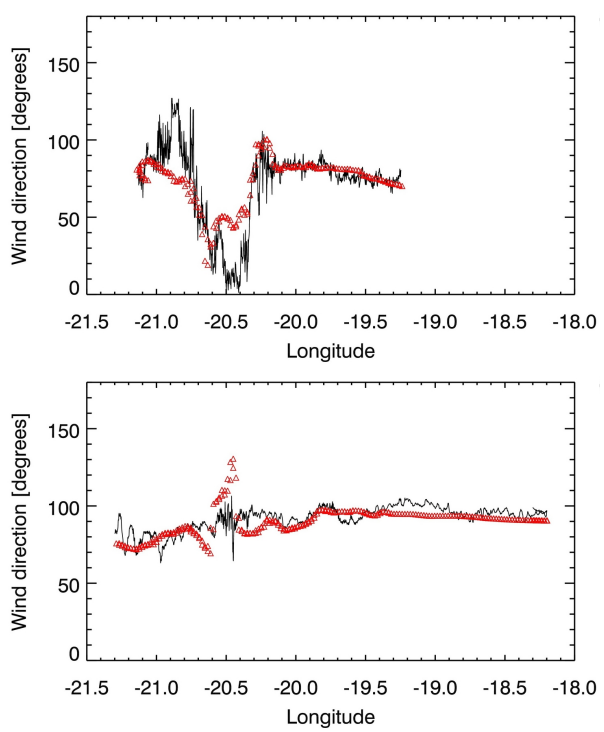

Fig. 10. Aircraft measurements (black lines) and G3 simulations from the run MPR (red triangles) at (a) $400 \mathrm{~m}$ height, (b) $700 \mathrm{~m}$ height and (c) $1900 \mathrm{~m}$ height. Wind speed $\left[\mathrm{m} \mathrm{s}^{-1}\right.$ ] is shown by panels on the left and wind direction [degrees] by panels on the right.

Measured mass mixing ratios and particle number concentrations do not change significantly from $400 \mathrm{~m}$ to $700 \mathrm{~m}$ height. However, the two peaks measured at $700 \mathrm{~m}$ are poorly simulated by the model. This could be due to less vertical mixing and more stable conditions between $400 \mathrm{~m}$ and $700 \mathrm{~m}$ height in the simulations than in the observations (see discussion of Fig. 11, above).

At $1900 \mathrm{~m}$ height, measured particle mass mixing ratios only reach values of about $33 \mu \mathrm{g} \mathrm{kg}-1$ in the area of the western peak which occured at the lower flight legs. The strong decrease of the values from $700 \mathrm{~m}$ to $1900 \mathrm{~m}$ height as well as the shape of the measurements at $1900 \mathrm{~m}$ height is rather well represented by the model. In contrast to this, particle number concentration is poorly simulated at this height, with the measurements showing slightly higher values inside the jet, while simulations show a decrease towards values close to zero for longitudes to the east of about $20^{\circ} \mathrm{W}$.

Further inspection of the model results shows, that the simulated peak in particle number concentration at $1900 \mathrm{~m}$ height is due to sulfate and organic carbon which dominate at this flight level. This is in contrast to simulations of particle number concentrations at lower heights and in contrast to particle mass mixing ratio at all flight levels (including the highest one), which are all strongly dominated by dust and sea salt aerosols. Simulated sulfate and organic carbon may originate from volcanic emissions used to initialise the model and from biogenic emissions (calculated online and possibly also included in the initial conditions), respectively. As described earlier in this section, some precipitation (graupel and snow) is simulated for leg 3 which is not present in the 2DC and 2DP measurements. Therefore, unrealistic washout may contribute to the simulated decrease in particle concentration towards the jet. However, this decrease can also be partly explained by the increasing distance to land sources of sulfate and organic carbon towards the jet.

Fig. 13a shows measured particle number size distributions for three different regions which are called R1, R2 and $\mathrm{R} 3$ in the following (the location of these regions in terms of longitudes is given in the Figure caption). The regions were chosen based on simulated particle composition (see Fig. 12). $\mathrm{R} 1$ represents the wake and the area of increasing wind speed between the wake and the jet. In R1, simulated total particle number concentrations are dominated by dust. $\mathrm{R} 2$ shows that part of the jet, where the model simulates a mixture of dust and sea salt. R3 corresponds to the part of the jet which is dominated by sea salt aerosols. At $400 \mathrm{~m}$ and $700 \mathrm{~m}$ height, 
(a)

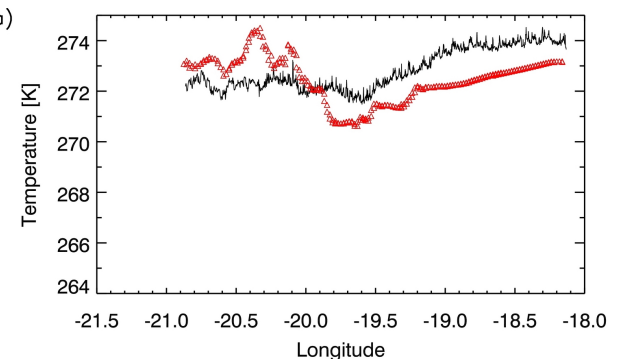

(b)

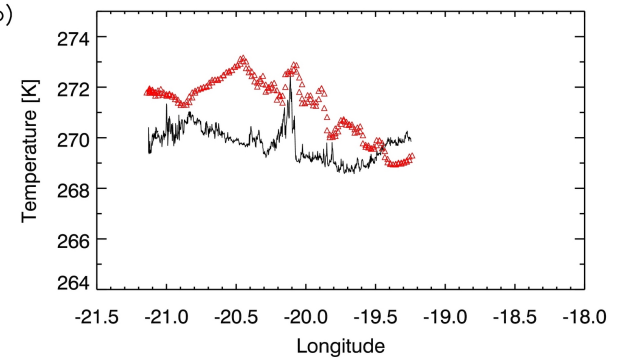

(c)

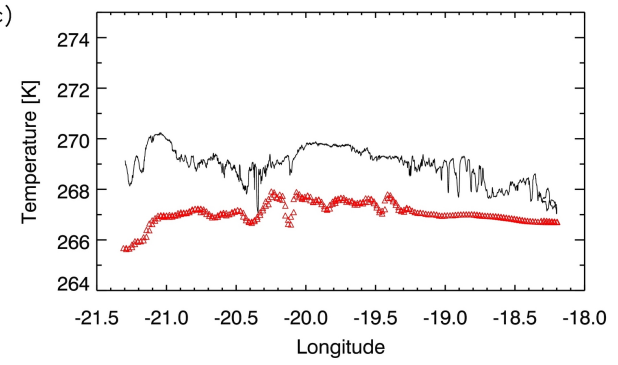

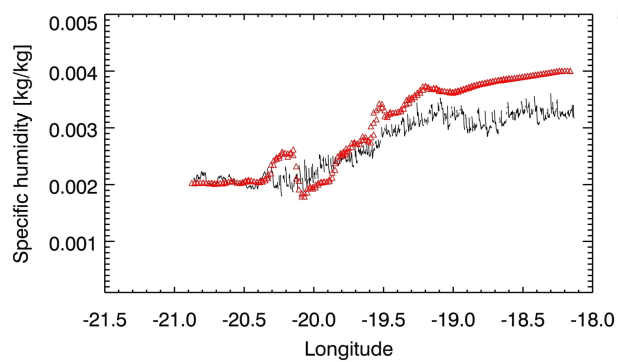
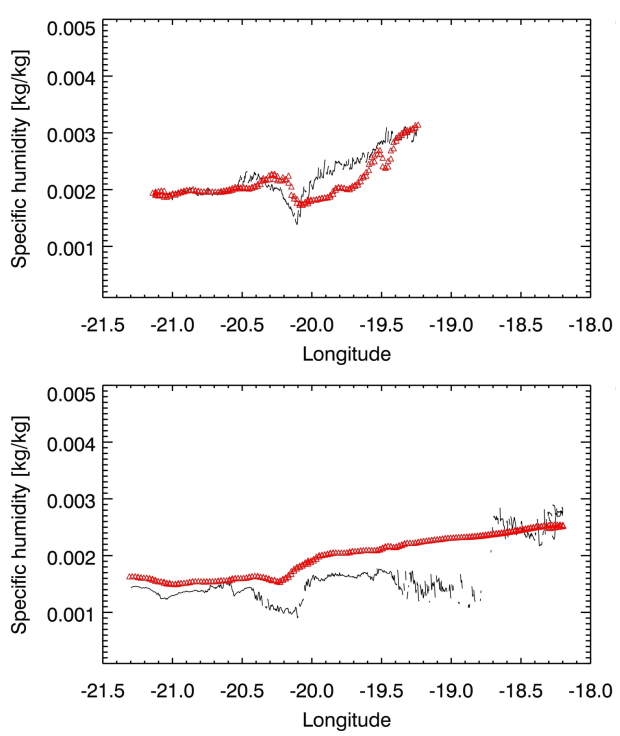

Fig. 11. As in Fig. 10 but for temperature $[\mathrm{K}]$ (panels on the left) and specific humidity $\left[\mathrm{kg} \mathrm{kg}^{-1}\right]$ (panels on the right).

the number of aerosols at larger diameters is much greater in $\mathrm{R} 1$, than in R2 and also in R3. At $1900 \mathrm{~m}$ height, the number of aerosols at larger diameters is still largest in R1. However, there are more larger sized particles in R3 than in R2 at this flight leg. The size distributions are very similar for $400 \mathrm{~m}$ and $700 \mathrm{~m}$ height, but there is a strong decrease in the magnitude of the values at $1900 \mathrm{~m}$ height in agreement with Fig. 12.

Simulated particle number size distributions for the three regions are shown in Fig. 13b. The model generally fails to simulate the shape and magnitude of the measured size distributions, especially for R1 and R2. However, the decrease in the values at $1900 \mathrm{~m}$ height is largely reproduced, but only for R2 and R3. Moreover, the number of aerosols at larger diameters is largest in R1 which is in agreement with the measurements. Overall, the shape of the size distributions is better simulated for R3 than for R1 and R2.

The fact that number size distributions are poorly simulated by the model may explain why simulated and measured particle number concentrations agree much better in magnitude than the corresponding particle mass mixing ratios (see Fig. 12). In OPR and MPR, mass fractions are used to apportion total dust mass mixing ratios into the different size bins. The particle number concentrations are calculated by divid- ing particle mass mixing ratios by the particle density and particle volume for each size bin. As the model assumes particle sphericity, the volume in each size bin is proportional to the particle radius to the power of three. This means that small errors in mass fractions can lead to much larger errors in mass mixing ratios than in number concentrations. Uncertainties in simulating processes like particle coagulation and condensation may also contribute to errors in simulated number size distributions.

Total scattering measured by a nephelometer at $700 \mathrm{~nm}$ (red), $550 \mathrm{~nm}$ (green) and $450 \mathrm{~nm}$ (blue) wavelength on board the FAAM aircraft shows the same features as the measured particle mass mixing ratios in Fig. 12, i.e. an overall decrease from the wake towards the jet and a two peak pattern, and are therefore not shown here. At $700 \mathrm{~nm}$ wavelength and at $400 \mathrm{~m}$ height, values of up to $8 \times 10^{-4} \mathrm{~m}^{-1}$ were reached at the location of the two maxima in particle mass mixing ratio. However, the scattering ratio of red to green and red to blue which gives information on the ratio of larger to smaller sized particles (e.g. if red scattering is larger than blue and green scattering, then larger mode particles dominate the particle composition) is shown in Fig. 14. At $400 \mathrm{~m}$ and $700 \mathrm{~m}$ height, there is a strong decrease in the red to blue scattering ratio around $19.5^{\circ} \mathrm{W}$ indicating a change in composition at 

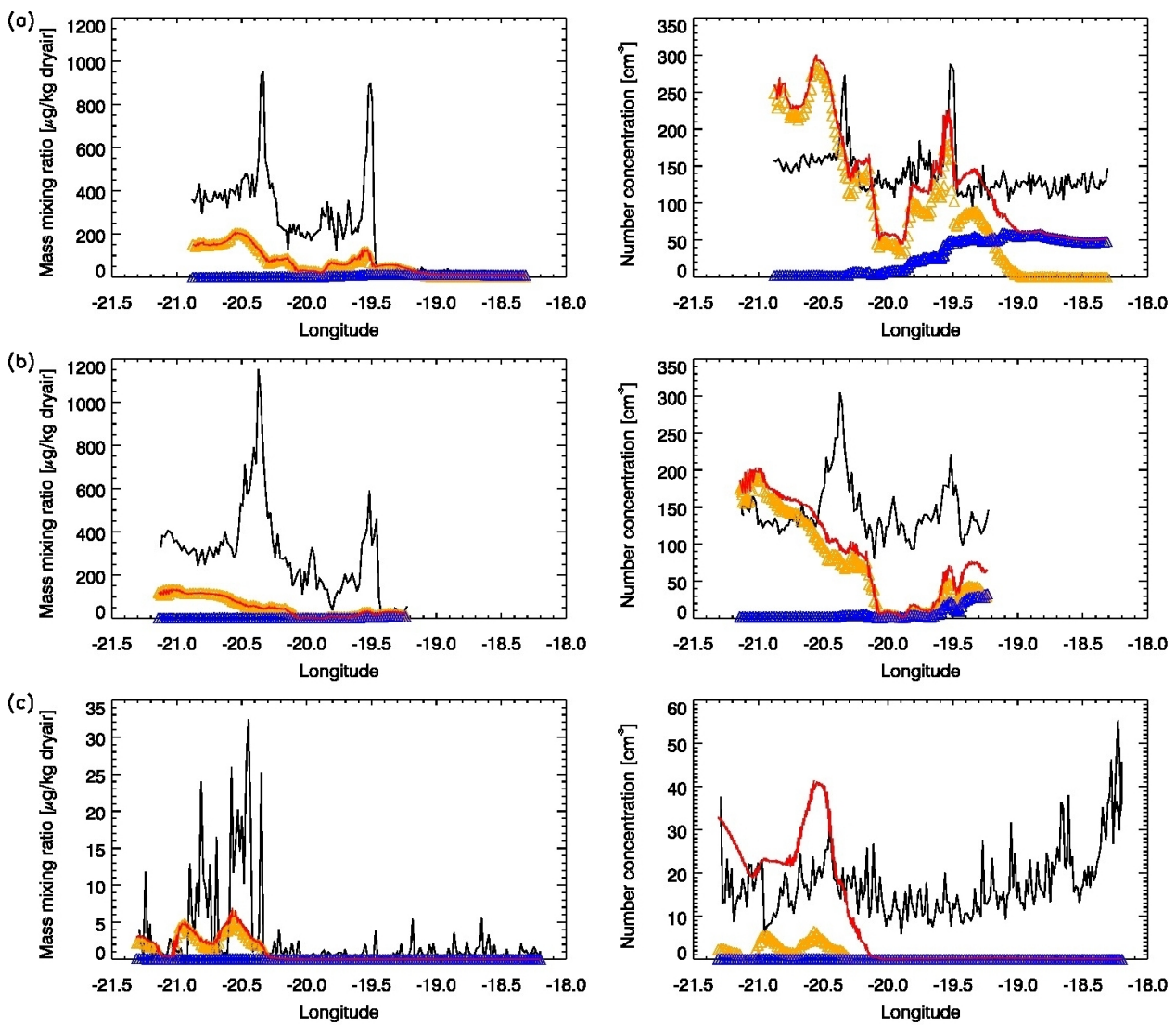

Fig. 12. As in Fig. 10 but for particle mass mixing ratio $\left[\mu \mathrm{g} \mathrm{kg}^{-1}\right]$ (panels on the left) and particle number concentration [ $\left.\mathrm{cm}^{-3}\right]($ panels on the right). The black line correspond to 10 second averages of aircraft measurements from PCASP. The red line shows the sum of all simulated aerosol types (i.e. dust, sea salt, black carbon, organic carbon, ammonium, nitrate and sulfate). Orange triangles show simulated dust and blue triangles simulated sea salt. Model results are only shown for diameters between $0.133 \mu \mathrm{m}$ and $4.05 \mu \mathrm{m}$ to allow comparison to the PCASP measurements.

this longitude. The same is true for red to green, but at $400 \mathrm{~m}$ height the decrease is less pronounced for red to green compared to red to blue. Scattering ratios for red to blue and red to green are larger than one at $400 \mathrm{~m}$ height indicating that the aerosol composition is dominated by coarser mode particles. At $700 \mathrm{~m}$ height smaller mode particles seem to dominate eastwards of approximately $19.5^{\circ} \mathrm{W}$. This in agreement with the model simulations (see Fig. 12), for which dust dominates inside the wake, while sea salt dominates towards the jet. Scattering ratios for $1900 \mathrm{~m}$ height are not regarded here, because of the poor signal to noise ratio due to low particle number concentrations occuring at this flight leg.

Figure 15 shows measured and simulated particle mass mixing ratios and particle number concentrations for OPR. This model set up significantly underestimates the magnitude of particle mass mixing ratios and particle number concentrations. The underestimation is more pronounced than for MPR, which shows much larger values compared to OPR. However, the main features of the measurements, i.e. a decrease in particle mass mixing ratio and particle number concentration from the wake towards the jet, are captured.
The two peak pattern measured by the aircraft at $400 \mathrm{~m}$ and $700 \mathrm{~m}$ height is not present in OPR.

Overall, changes applied to the dust and sea salt parameterisation in MPR have improved the simulations of dust and sea salt aerosols near Iceland. However, particle number size distributions and the magnitude of particle mass mixing ratios are poorly simulated by the model. Especially the mass fractions used within the dust parameterisation to apportion dust into different size bins, need to be checked in future modelling studies of Icelandic dust storms. Uncertainties remain in MPR associated with the snow cover (especially for G1 and G2), other assumptions made in dust and sea salt parameterisations and contributions from emission sources neglected by our model set up.

Furthermore, assumptions on optical properties of the aerosols that were sampled during the flight lead to an uncertainty in the aircraft measurements from PCASP (see Sect. 3). However, these uncertainties do not seem to account for the differences in simulations and measurements described in the present paper. 
(a)

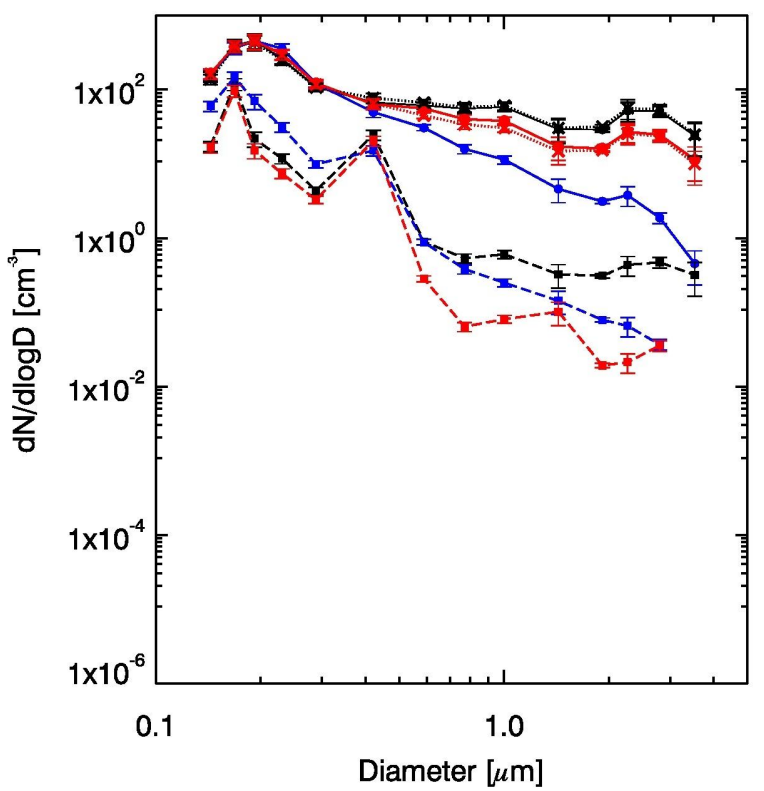

(b)

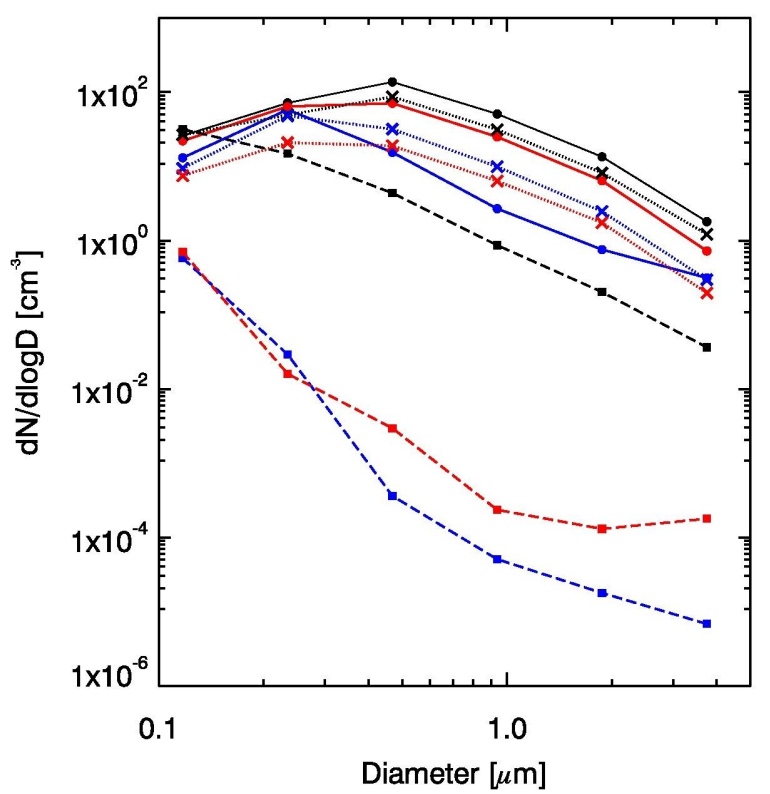

Fig. 13. Particle number size distributions $\left[\mathrm{cm}^{-3}\right]$ from (a) aircraft measurements (PCASP) and (b) G3 simulations. Different colors denote three regions: (R1, black) longitudes to the west of $20^{\circ} \mathrm{W}$, (R2, red) longitudes between $20^{\circ} \mathrm{W}$ and $19.1^{\circ} \mathrm{W}$, and (R3, blue) longitudes eastwards of $19.1^{\circ} \mathrm{W}$. The symbols and linestyles correspond to the three flight legs: solid lines with dots show $400 \mathrm{~m}$ height, dotted lines with crosses $700 \mathrm{~m}$ height, and dashed lines with squares show $1900 \mathrm{~m}$ height. Vertical bars in panel (a) show 3 -sigma uncertainties associated with the measurements. Note that the $700 \mathrm{~m}$ flight leg (dotted lines with crosses) can barely be distinguished from the $400 \mathrm{~m}$ flight leg in panel (a), since the size distributions are quite similar at these heights. R3 was not investigated during the $700 \mathrm{~m}$ flight leg and hence does not appear in panel (a). (o)

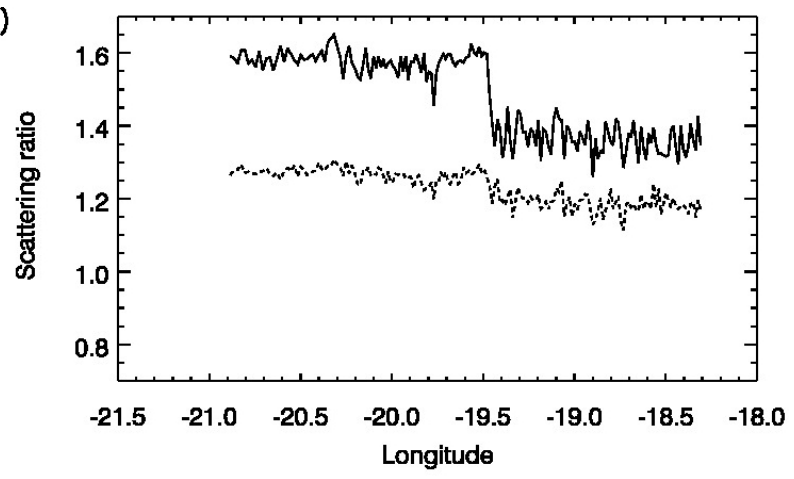

(b)

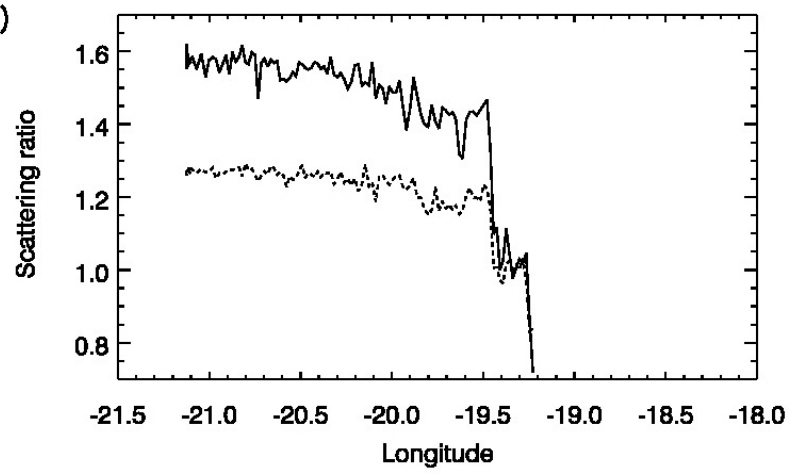

Fig. 14. Aircraft measurements of scattering ratio from the Rosemount pair inlet nephelometer for (a) $400 \mathrm{~m}$ height and (b) $700 \mathrm{~m}$ height. The values shown are 10 second averages. The solid line shows the ratio between red and blue, the dashed line the ratio between red and green. Note that scattering ratios for $1900 \mathrm{~m}$ height are not shown here, because of the poor signal to noise ratio due to low particle number concentrations occuring at this flight leg.

\subsection{Flexpart simulations}

Figure 16 shows PES for the aerosol tracer for flight legs 5 and 3. Results for flight leg 4 are very similar to flight leg 5 and are therefore not shown here. Backward simulations were started on 22 February at 11:57 UTC and 10:53 UTC for leg 5 and 3, respectively. These are times when the aircraft was located inside the wake. The plume centroid locations, derived from a statistical cluster analysis (see Stohl et al., 2005 and Stohl et al., 2002), for up to 6 days backward in time are represented by black circles. The sequence of centroids backward in time can be regarded as a trajectory back from the measurement location, if a plume does not split significantly.

At $400 \mathrm{~m}$ height (Fig. 16a), PES shows the highest values in the northeasterly flow over South Iceland. There is high sensitivity over Icelandic dust emission source regions. Centroid locations suggest that the airmasses investigated by the aircraft originated from Scandinavia two to five days ahead of the flight day, but were then transported over the Norwegian Sea towards Iceland.

For flight leg 3 (Fig. 16b), centroids take a clockwise track backward in time from Iceland towards Greenland. The PES 

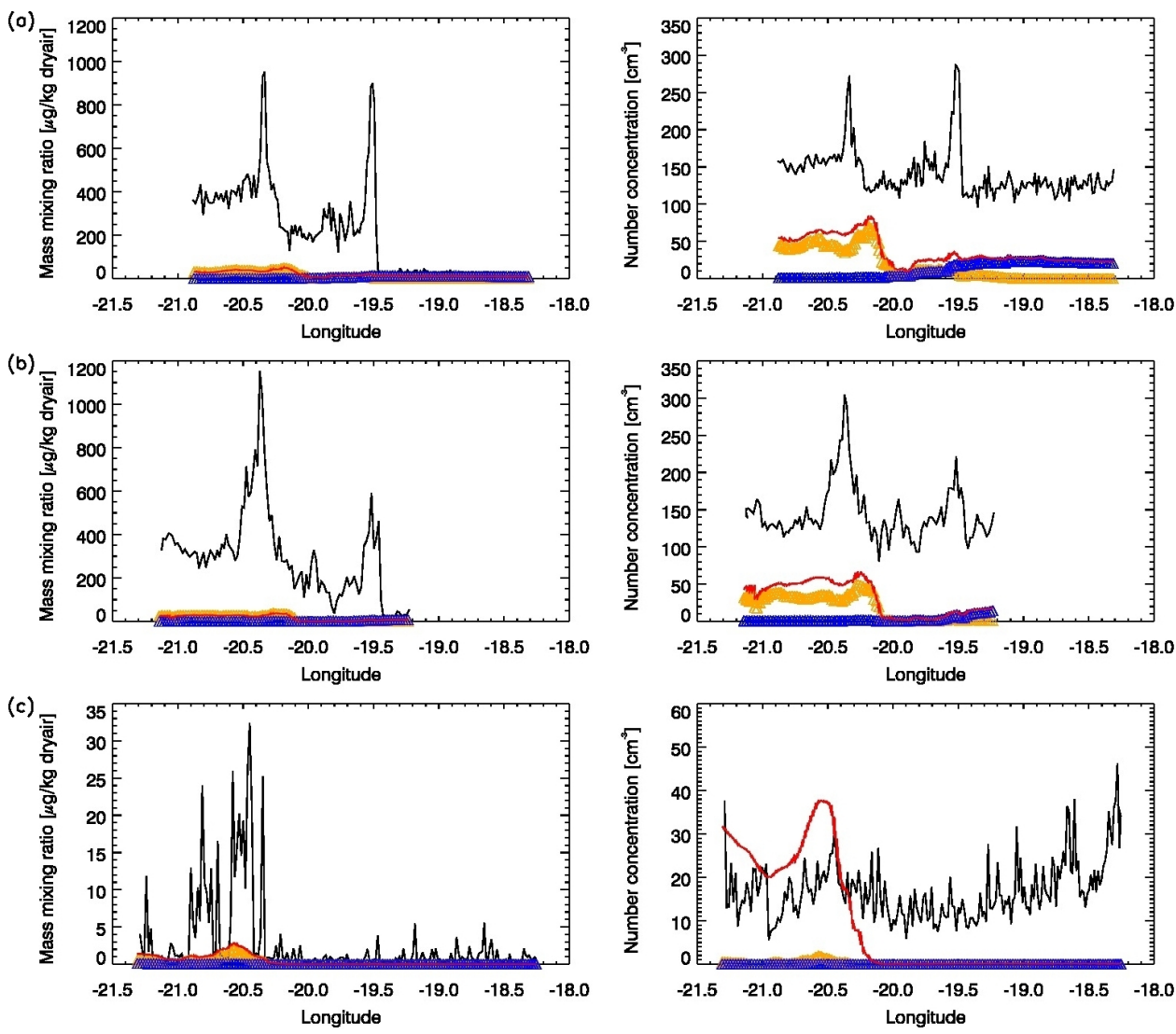

Fig. 15. As in Fig. 12 but for model results from the run OPR.

in the cyclonic flow to the south of Iceland is higher compared to Flexpart simulations for flight leg 5.

Note that Flexpart simulations were also carried out for times when the aircraft was located inside the jet (not shown). These simulations indicate that the air was of much more maritime origin, which is in agreement with the WRF/Chem results (see Sect. 5.1). The results basically show the same as for times when the aircraft was located inside the wake.

Overall, Flexpart simulations suggest significantly different air mass histories for the $1900 \mathrm{~m}$ flight leg and the lower elevation legs. This is in agreement with the WRF/Chem simulations which show that the amount of dust has significantly decreased at this level.

\section{CALIPSO observations}

Although simulations presented here focus on the flight day, wind data from the QuikSCAT satellite (not shown) reveal that comparable wind speed conditions (i.e. wind speeds of more than $20 \mathrm{~m} \mathrm{~s}^{-1}$ and a barrier jet and wake pattern) were already present on 20 February and lasted until approximately 23 February. This implies that the dust storm may already have developed some time before the flight was carried out. In fact, the meteorological station Stórhöfði (see Fig. 4) also reported dust for the morning of 21 February. There is further evidence from the Cloud Aerosol Lidar with Orthogonal Polarization (CALIOP) on board the Cloud-Aerosol Lidar Infrared Pathfinder Satellite Observation (CALIPSO) satellite that dust and marine aerosols were present on 21 February near Iceland's south coast.

Figure 17a shows the CALIPSO track plotted on top of cloud top pressure from MODIS for the morning of 21 February. The vertical aerosol type profile for this CALIPSO track is given in Fig. 17b. The CALIOP data shows marine aerosols and dust aerosols over the ocean near Iceland's south coast. CALIPSO also detected a lot of dust and polluted dust over the north-western Icelandic land surface. However, the widespread presence of dust for latitudes larger than $64.75^{\circ} \mathrm{N}$ in the area of the CALIPSO track is unlikely, given that north-easterly wind directions prevailed close to the time of the CALIOP observation (see Fig. 2 of http://www.atmos-chem-phys-discuss.net/12/ C2459/2012/acpd-12-C2459-2012-supplement.pdf) and that most parts of north-west Iceland were covered by snow (see Sect. 4.1.1). Moreover, MODIS detected some low level clouds over the ocean to the north of $64^{\circ} \mathrm{N}$ which do not show up in the CALIPSO profile. Clouds to the north of approximately $65^{\circ} \mathrm{N}$ seem to be present in both, MODIS and 
(a)

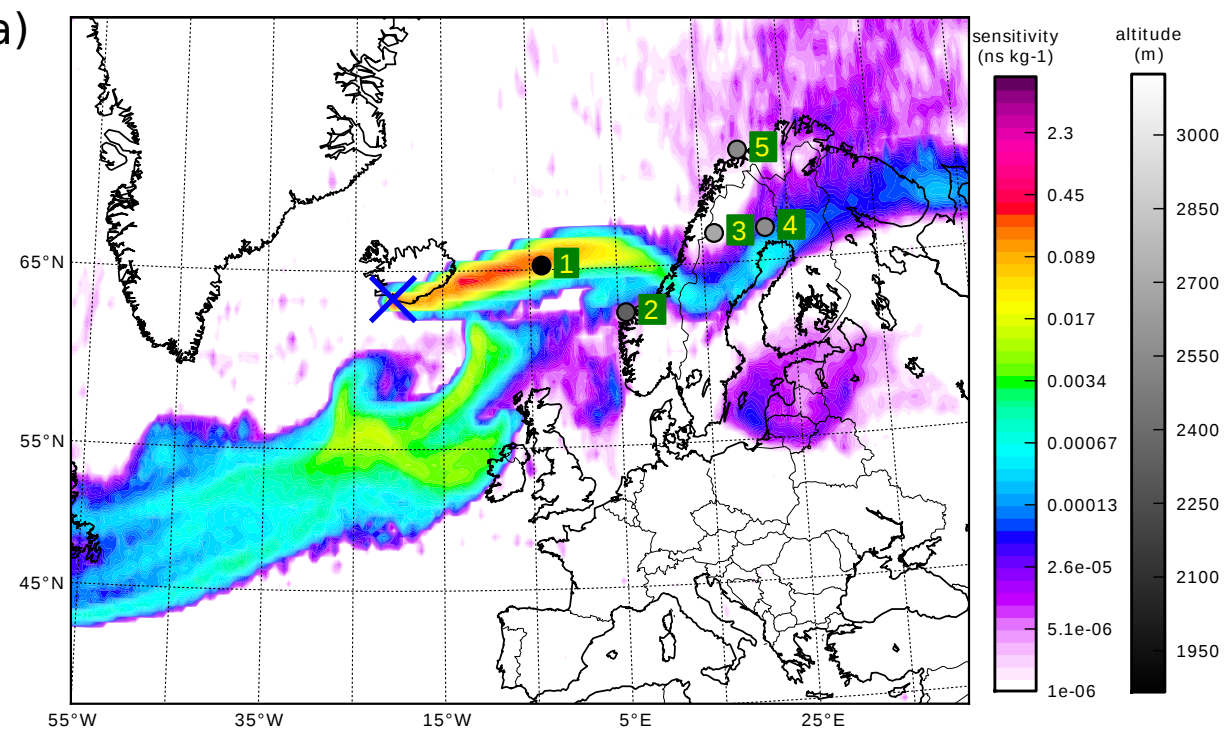

(b)

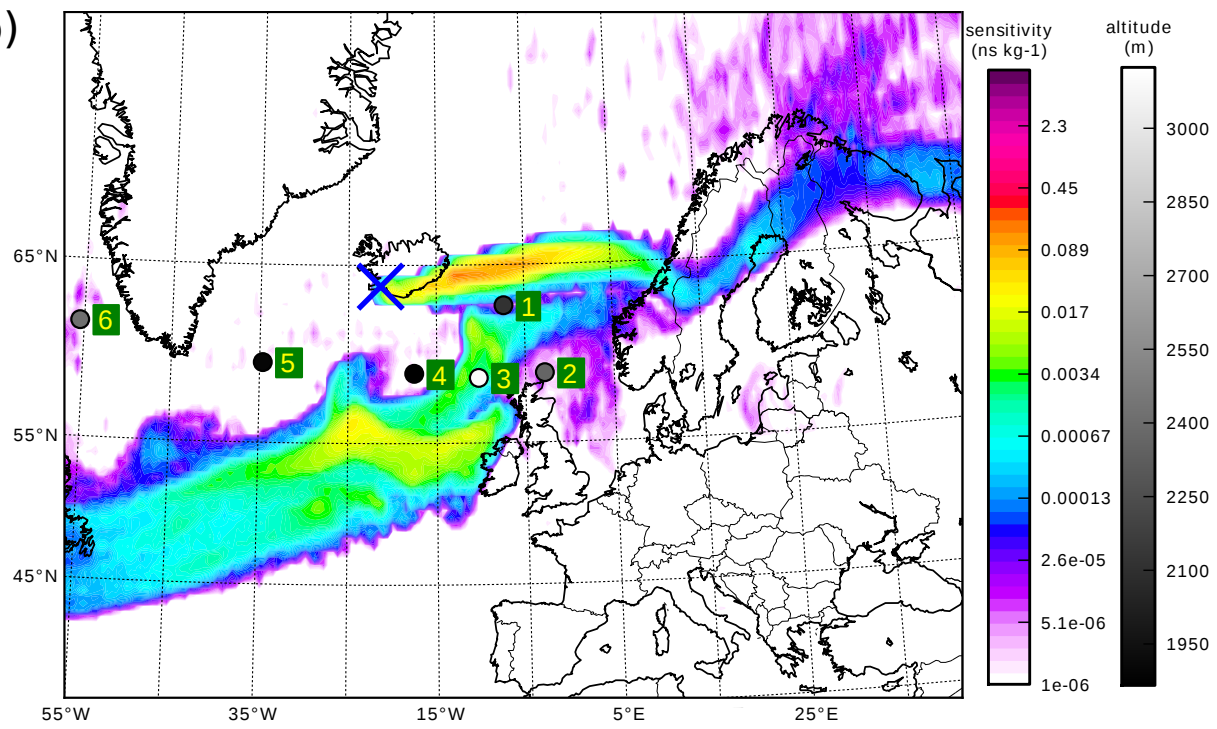

Fig. 16. Flexpart aerosol tracer footprint PES [ns/kg] (colored shadings) for (a) flight leg 5 (400 m height) and (b) flight leg 3 (1900 m height). Black circles represent plume centroid locations for a specific day back in time (see yellow numbers inside green boxes to the right of the circles for the corresponding day back in time). The circles are filled with a grey shading that represents the mean plume altitude [m]. The blue crosses near Iceland mark the aircraft measurement location.

CALIOP observations. The clouds seen by MODIS may have been misclassified by CALIPSO as dust given that CALIPSO also detected dust to the north of $64.75^{\circ} \mathrm{N}$, which seems to be unlikely (see above). Information on uncertainties associated with CALIPSO version 3.01 products (which were investigated here) is given by Kacenelenbogen et al. (2011).

\section{$7 \quad$ Summary and conclusions}

A dust storm at southern Iceland which occurred in a barrier jet event during GFDex has been investigated based on aircraft observations and the mesoscale model WRF/Chem.
The results document the transport of dust from Icelandic sand fields towards the ocean, thereby significantly reducing the visibility near Iceland's south coast.

Changes have been applied to the dust and sea salt parameterisations to make WRF/Chem capable of simulating Icelandic dust storms. These improve simulations of dust and sea salt aerosols near Iceland. However, rather large discrepancies remain concerning simulated and measured particle mass mixing ratios and particle number size distributions, especially in regions dominated by dust. This is most likely related to mass fractions used within the model to apportion dust aerosols into different size bins. The mass fractions for 
(o)

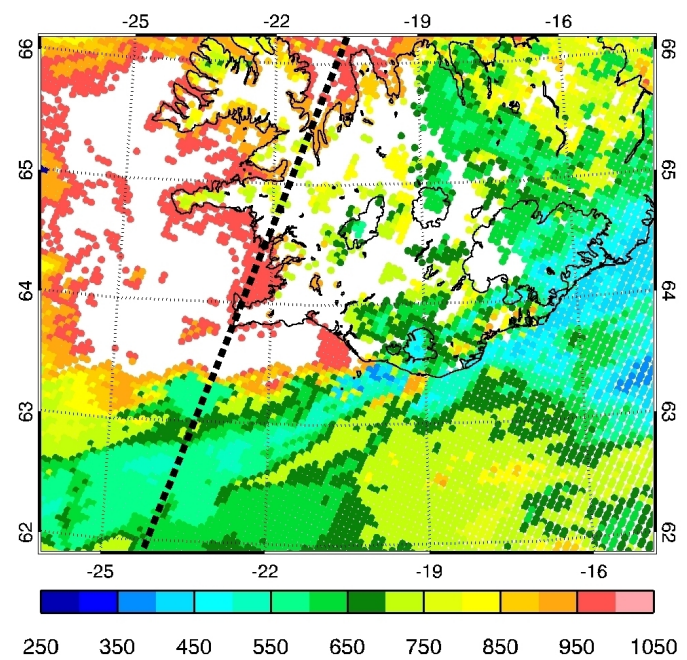

(b)

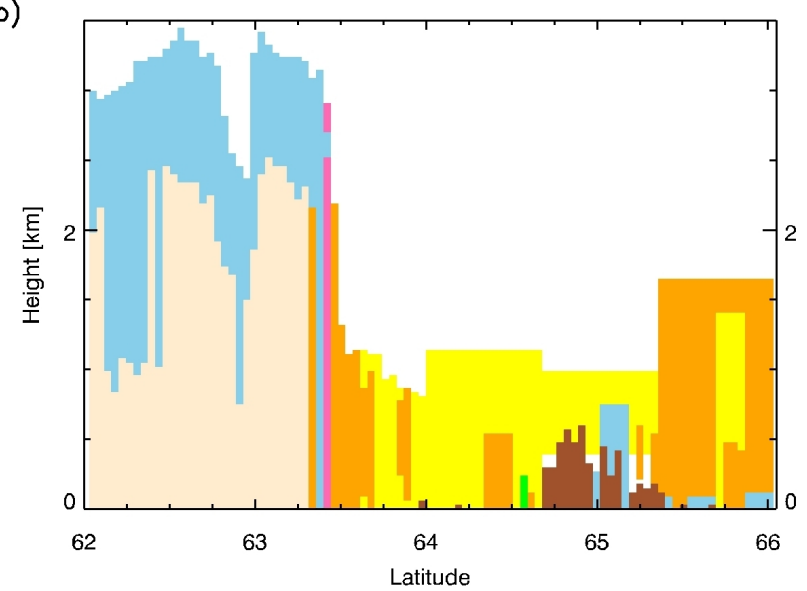

Fig. 17. Satellite observations on 21 February by CALIOP at 04:15 UTC and MODIS Aqua at 04:20 UTC. Panel (a) shows the CALIPSO track (black dotted line), plotted on top of MODIS cloud top pressure $[\mathrm{hPa}]$ (colored shadings). Panel (b) shows the vertical profile of aerosol type from CALIOP (white - clear air, blue cloud, beige - no signal, brown - surface, green - clean continental, yellow - dust, orange - polluted dust, pink - clean marine).

dust need to be checked in future modelling studies of Icelandic dust storms. Processes like particle coagulation and condensation also add an uncertainty to dust and sea salt simulations which should be investigated. The model results look much better for particle number concentrations, but there is a tendency for WRF/Chem to overestimate dust inside the wake and to underestimate sea salt inside the jet. The simulations could be improved by including the most up to date information on snow cover, by testing other values for erodable fractions ( $\alpha$ values) assumed for vegetation types and by further optimisation of the dust and sea salt parameterisations. Inclusion of data from a global chemical transport model for initial and boundary conditions and other emission sources not taken into account in our model set up could also improve the simulations, especially for the upper flight leg at $1900 \mathrm{~m}$ height.

Although the snow free sand fields over South and West Iceland seem to be reasonably represented by the USGS data set, simulations may improve by testing other vegetation maps in order to simulate Icelandic vegetation characteristics more realistically. Moreover, it should be checked how the representation of vegetation in the model corresponds to the localised dust hot spots shown by satellite images in previous studies (e.g. Thorsteinsson et al., 2011; Prospero et al., 2012). Note however, that WRF/Chem has been used here primarily to better characterise the type of particles sampled by the aircraft and that this aim was achieved satisfactorily using the USGS vegetation map.

Thorsteinsson et al. (2011) and Prospero et al. (2012) describe Landeyjasandur (a sandy area located along the southeast coast of Iceland at approximately $63.73^{\circ} \mathrm{N}, 20.67^{\circ} \mathrm{W}$ ) as an important dust source. Thorsteinsson et al. (2011) reported on dust transport from this area towards Reykjavík. In the present study, large parts of Landeyjasandur were located inside the low wind speed wake area on the flight day, which did not favor the production of wind-blown dust at this area. Moreover, the prevailing north-easterly wind directions precluded dust transport towards Reykjavík. This is in agreement with the observations described in Sect. 3. Given that large parts of north-east Iceland were covered by snow and that north-easterly winds prevailed on the flight day, we conclude that the low visbility inside the wake was most likely completely caused by dust transport from sand fields along Iceland's south coast, including the sources around Mýrdalsjökull suggested by the WRF/Chem simulations. Sources to the west of Vatnajökull (located outside the high-resolution domain) also seem to be activated in the simulations and may have contributed to the low visibility inside the wake area.

The location of local wind speed maxima relative to dust maxima indicates that orographic effects may have contributed to the formation of the dust storm. Results presented here highlight the usefulness of a high resolution model for simulating Icelandic dust storms, which is in agreement with Ólafsson (2005). Local wind speed maxima associated with orography will most likely not be adequately represented by global climate models. Assuming that orographic effects contribute to the majority of Icelandic dust storms, these effects should be parameterised in global climate models. Moreover, Icelandic dust storms in a warmer climate should be investigated in future studies. Icelandic glaciers have been retreating in recent decades. Since this trend is expected to continue with global warming, Icelandic dust activity may increase in the future (Prospero et al., 2008; Prospero et al., 2012).

Icelandic sand originates to a large extent from volcanic fly ash (e.g. Arnalds et al., 2001). However, not much is known on the exact composition of wind blown Icelandic dust. In this sense, it should be investigated if the volcanic glass contained in Icelandic dust could pose a risk to aviation. 
Iceland is an important global source of dust with deposition rates comparable to or higher than those found for other areas that are usually considered to contribute to major global dust emissions (Arnalds, 2010; Prospero et al., 2012). In agreement with the results of the present study, Ovadnevaite et al. (2009) showed that dust outbreaks from Iceland can increase levels of absorbing material and light scattering over the North Atlantic. Ovadnevaite et al. (2009) concluded that dust from Icelandic sand fields may be a significant regional source of aerosols over the North Atlantic and hence should be considered in regional and global climate models. Future studies are required to determine the implications of an inadequate representation of Icelandic dust sources in climate simulations.

To our knowledge, apart from the record by Prospero et al. (2012), no comprehensive data set describing the frequency of Icelandic dust storms exists. Although in-situ data have been used together with visible satellite imagery from passive remote sensors (e.g. Ovadnevaite et al., 2009; Arnalds, 2010; Prospero et al., 2012) to verify the transport of dust from Iceland towards the ocean, this method is only successful for dust storms which are not hidden by clouds. Active remote sensors like CALIOP on board CALIPSO can look through clouds to some extent, but their poor spatial coverage would prohibit the derivation of a meaningful climatology. This means that a combined approach, using numerical models, satellites and measurements is required to derive statistics about Icelandic dust storms.

Overall, the modelling approach presented here constitutes a promising basis to investigate important questions on Icelandic dust storms addressed in this section.

Acknowledgements. This work was funded by the Norwegian Research Council through the POLARCAT project, project no. 175916. The corresponding author was previously funded by the Natural Environment Research Council (NERC) through its National Centre for Atmospheric Science (NCAS) and is now working at the University of Bremen. Thanks to the British Atmospheric Data Centre (BADC), which is part of NCAS, for providing the GFDex data on their web page. Acknowledged are the people behind the CISL Research Data Archive for providing NCEP data on their web site. Thanks to the European Centre for Medium-Range Weather Forecasts (ECMWF) and the Norwegian Meteorological Institute for providing access to ECMWF data. We also thank Dr. Kate Turnbull from the UK Met Office for helpful comments on FAAM data. Thanks to FAAM for operating the BAe-146 aircraft. CALIPSO data were obtained from the NASA (National Aeronautics and Space Administration) Langley Research Center Atmospheric Science Data Center. MODIS true-color images were received from the NASA/GSFC Rapid Response system (http://lance.nasa.gov/imagery/rapid-response/) and MODIS data obtained from http://modis.gsfc.nasa.gov/. SST images from www.remss.com are produced by Remote Sensing Systems and sponsored by National Oceanographic Partnership Program (NOPP), the NASA Earth Science Physical Oceanography Program, and the NASA MEaSUREs DISCOVER Project. QuikSCAT data were obtained from the Physical Oceanography Distributed Active Archive Center (PO.DAAC) at the NASA Jet Propulsion Laboratory, Pasadena, California (http://podaac.jpl.nasa.gov).

Edited by: E. Highwood

\section{References}

Arnalds, O.: The Icelandic 'rofabard' soil erosion features, Earth Surf. Process. Landforms, 25, 17-28, 2000.

Arnalds O.: Dust sources and deposition of aeolian materials in Iceland, Icel. Agric. Sci., 23, 3-21, 2010.

Arnalds, O., Gisladottir, F. O., and Sigurjonsson, H.: Sandy deserts of Iceland: an overview, J. Arid Environ., 47, 359-371, 2001.

Bukowiecki, N., Zieger, P., Weingartner, E., Jurányi, Z., Gysel, M., Neininger, B., Schneider, B., Hueglin, C., Ulrich, A., Wichser, A., Henne, S., Brunner, D., Kaegi, R., Schwikowski, M., Tobler, L., Wienhold, F. G., Engel, I., Buchmann, B., Peter, T., and Baltensperger, U.: Ground-based and airborne in-situ measurements of the Eyjafjallajökull volcanic aerosol plume in Switzerland in spring 2010, Atmos. Chem. Phys., 11, 10011-10030, doi:10.5194/acp-11-10011-2011, 2011.

Crochet, P., Jóhannesson, T., Jónsson, T., Sigurdsson, O., Björnsson, H., Pálsson, F., and Barstad, I.: Estimating the spatial distribution of precipitation in Iceland using a linear model of orographic precipitation, J. Hydrometeorol., 8, 1285-1306, 2007.

ECMWF: IFS Documentation, edited by: White, P. W., ECMWF, Reading, UK, 2002.

Gilman, J. B., Burkhart, J. F., Lerner, B. M., Williams, E. J., Kuster, W. C., Goldan, P. D., Murphy, P. C., Warneke, C., Fowler, C., Montzka, S. A., Miller, B. R., Miller, L., Oltmans, S. J., Ryerson, T. B., Cooper, O. R., Stohl, A., and de Gouw, J. A.: Ozone variability and halogen oxidation within the Arctic and sub-Arctic springtime boundary layer, Atmos. Chem. Phys., 10, 10223-10236, doi:10.5194/acp-10-10223-2010, 2010.

Gong, S. L.: A parameterization of sea-salt aerosol source function for sub- and super-micron particles, Global Biogeochem. Cy., 17, 1097, doi:10.1029/2003GB002079, 2003.

Gong, S. L. and Barrie, L. A.: Modeling sea-salt aerosols in the atmosphere - 1. Model development, J. Geophys. Res., 102, 38053818, doi:10.1029/96JD02953, 1997.

Grell, G. A., Peckham, S. E., Schmitz, R., McKeen, S. A., Frost, G., Skamarock, W. C., and Eder, B.: Fully coupled 'online' chemistry within the WRF model, Atmos. Environ., 39, 6957-6976, doi:10.1016/j.atmosenv.2005.04.027, 2005.

Guenther, A., Zimmerman, P., and Wildermuth, M.: Natural volatile organic compound emission rate estimates for US woodland landscapes, Atmos. Environ., 28, 1197-1210, 1994.

Gustafson Jr., W. I., Qian, Y., and Fast, J. D.: Downscaling Aerosols and the Impact of Neglected Subgrid Processes on Direct Aerosol Radiative Forcing for a Representative Global Climate Model Grid Spacing, J. Geophys. Res., 116, D13303, doi:10.1029/2010JD015480, 2011.

Hirdman, D., Burkhart, J. F., Sodemann, H., Eckhardt, S., Jefferson, A., Quinn, P. K., Sharma, S., Ström, J., and Stohl, A.: Longterm trends of black carbon and sulphate aerosol in the Arctic: changes in atmospheric transport and source region emissions, Atmos. Chem. Phys., 10, 9351-9368, doi:10.5194/acp-10-93512010, 2010. 
Ingólfsson, Ó.: The dynamic climate of Iceland, http://www3.hi.is/ oi/climate_in_iceland.htm (last access: 16 January 2012), 2008.

Jacobson, M. Z.: Fundamentals of atmospheric modelling, Cambridge University Press, p. 302, 1999.

Jonson, J. E., Stohl, A., Fiore, A. M., Hess, P., Szopa, S., Wild, O., Zeng, G., Dentener, F. J., Lupu, A., Schultz, M. G., Duncan, B. N., Sudo, K., Wind, P., Schulz, M., Marmer, E., Cuvelier, C., Keating, T., Zuber, A., Valdebenito, A., Dorokhov, V., De Backer, H., Davies, J., Chen, G. H., Johnson, B., Tarasick, D. W., Stübi, R., Newchurch, M.J., von der Gathen, P., Steinbrecht, W., and Claude, H.: A multi-model analysis of vertical ozone profiles, Atmos. Chem. Phys., 10, 5759-5783, doi:10.5194/acp-10-57592010, 2010.

Kacenelenbogen, M., Vaughan, M. A., Redemann, J., Hoff, R. M., Rogers, R. R., Ferrare, R. A., Russell, P. B., Hostetler, C. A., Hair, J. W., and Holben, B. N.: An accuracy assessment of the CALIOP/CALIPSO version 2/version 3 daytime aerosol extinction product based on a detailed multi-sensor, multi-platform case study, Atmos. Chem. Phys., 11, 3981-4000, doi:10.5194/acp-11-3981-2011, 2011.

Lin, Y.-L., Farley, R. D., and Orville, H. D.: Bulk parameterization of the snow field in a cloud model, J. Climate Appl. Meteor., 22, 1065-1092, 1983.

Liu, P. S. K., Leaitch, W. R., Strapp, J. W., and Wasey, M. A.: Response of Particle Measuring Systems Airborne ASASP and PCASP to $\mathrm{NaCl}$ and Latex Particles, Aerosol Sci. Tech., 16, 8395, 1992, doi:10.1080/02786829208959539.

Mårtensson, E. M., Nilsson, E. D., de Leeuw, G., Cohen, L. H., and Hansson, H.-C.: Laboratory simulations and parameterization of the primary marine aerosol production, J. Geophys. Res., 108, 4297, doi:10.1029/2002JD002263, 2003.

McConnell, C. L., Formenti, P., Highwood, E. J., and Harrison, M. A. J.: Using aircraft measurements to determine the refractive index of Saharan dust during the DODO Experiments, Atmos. Chem. Phys., 10, 3081-3098, doi:10.5194/acp-10-30812010, 2010.

Monahan, E. C., Spiel, D. E., and Davidson, K. L.: A model of marine aerosol generation via whitecaps and wave disruption, in Oceanic Whitecaps, edited by: Monahan, E. C. and MacNiochaill, G., 167-174, D. Reidel, Norwell, MA, USA, 1986.

Nickovic, S., Kallos, G., Papadopoulos, A., and Kakaliagou, O.: A model for prediction of desert dust cycle in the atmosphere, J. Geophys. Res., 106, 18113-18129, 2001.

Nilsson, E. D., Rannik, U., Swietlicki, E., Leek, C., Aalto, P. P., Zhou, J., and Norman, M.: Turbulent aerosol fluxes over the Arctic Ocean 2. Wind-driven sources from the sea, J. Geophys. Res., 106, 32139-32154, doi:10.1029/2000JD900747, 2001.

Nilsson, E. D., Mårtensson, E. M., Van Ekeren, J. S., de Leeuw, G., Moerman, M., and O'Dowd, C.: Primary marine aerosol emissions: size resolved eddy covariance measurements with estimates of the sea salt and organic carbon fractions, Atmos. Chem. Phys. Discuss., 7, 13345-13400, doi:10.5194/acpd-713345-2007, 2007.

O'Dowd, C. D. and Smith, M. H.: Physiochemical properties of aerosols over the northeast Atlantic: Evidence for wind-related submicron sea-salt aerosol production, J. Geophys. Res., 98, 1137-1149, doi:10.1029/92JD02302, 1993.

Ólafsson, H.: Multi-scale orographic forcing of the atmosphere leading to an erosion event, Proceedings of the 28th International
Conference on Alpine Meteorology (ICAM) and the Annual Scientific Meeting of the Mesoscale Alpine Programme (MAP), Zadar, Croatia, 2005.

Ólafsson, H., Petersen, G. N., Renfrew, I., Kristjánsson, J. E., and Moore, G. W.: The South-Iceland wake, in preparation, 2012.

Olivier, J. G. J. and Berdowski, J. J. M.: Global emissions sources and sinks, The Climate System, edited by: Berdowski, J., Guicherit, R., and Heij, B. J., A. A. Balkema Publishers/Swets and Zeitlinger Publishers, Lisse, The Netherlands, 33-78, 2001.

Ovadnevaite, J., Ceburnisa, D., Plauskaite-Sukieneb, K., Modinic, R., Dupuya, R., Rimselyteb, I., Ramonetd, M., Kvietkusb, K., Ristovskic, Z., Berresheima, H., and O'Dowd, C. D.: Volcanic sulphate and arctic dust plumes over the North Atlantic Ocean, Atmos. Environ., 43, 4968-4974, doi:10.1016/j.atmosenv.2009.07.007, 2009.

Patterson, E. M.: Measurements of the imaginary part of the refractive index between 300 and 700 nanometers for Mount St. Helens Ash, Science, 211, 836-838, doi:10.1126/science.211.4484.836, 1981.

Patterson, E. M., C. O. Pollard, and Galindo, I., Optical properties of the ash from El Chichon Volcano, Geophys. Res. Lett., 10, 317-320, doi:10.1029/GL010i004p00317, 1983.

Peckham, S. E., Grell, G. A., McKeen, S. A., Fast, J. D., Gustafson, W. I., Ghan, S. J., Zaveri, R., Easter, R. C., Barnard, J., Chapman, E., Wiedinmyer, C., Schmitz, R., Salzmann, M., and Freitas, S. R.: WRF/Chem Version 3.2 User's Guide, National Center for Atmospheric Research (NCAR), 2010.

Prospero, J. M., Arnalds, Ó., Ólafsson, H., Bullard, J. E., and Hodgkins, R.: Iceland dust storms linked to glacial outwash deposits and to sub-glacial flood (Jökulhlaup) events, AGU Fall Meeting 2008, San Francisco, USA, A13E-08, 2008.

Prospero, J. M., Bullard, J. E., and Hodgkins, R.: High-Latitude Dust Over the North Atlantic: Inputs from Icelandic Proglacial Dust Storms, Science, 335, 1078-1082, 2012.

Renfrew, I. A., Moore, G. W. K., Kristjánsson, J. E., Ólafsson, H., Gray, S. L., Petersen, G. N., Bovis, K., Brown, P., Fore, I., Haine, T. W. N., Hay, C., Irvine, E. A., Oghuishi, T., Outten, S. D., Pickart, R., Shapiro, M. A., Sproson, D., Swinbank, R., Wooley, A., and Zhang, S.: The Greenland Flow Distortion experiment, B. Am. Meteorol. Soc., 88, 1307-1324, 2008.

Rögnvaldsson, Ó., Jónsdóttir, J. F., and Ólafsson, H.: Numerical simulations of precipitation in the complex terrain of Icelandcomparison with glaciological and hydrological data, Meteorol. Z., 16, 71-85, 2007.

Rosenberg, P. D., Dean, A. R., Williams, P. I., Dorsey, J. R., Minikin, A., Pickering, M. A., and Petzold, A.: Particle sizing calibration with refractive index correction for light scattering optical particle counters and impacts upon PCASP and CDP data collected during the Fennec campaign, Atmos. Meas. Tech., 5, 1147-1163, doi:10.5194/amt-5-1147-2012, 2012.

Schumann, U., Weinzierl, B., Reitebuch, O., Schlager, H., Minikin, A., Forster, C., Baumann, R., Sailer, T., Graf, K., Mannstein, H., Voigt, C., Rahm, S., Simmet, R., Scheibe, M., Lichtenstern, M., Stock, P., Rüba, H., Schäuble, D., Tafferner, A., Rautenhaus, M., Gerz, T., Ziereis, H., Krautstrunk, M., Mallaun, C., Gayet, J.F., Lieke, K., Kandler, K., Ebert, M., Weinbruch, S., Stohl, A., Gasteiger, J., Groß, S., Freudenthaler, V., Wiegner, M., Ansmann, A., Tesche, M., Olafsson, H., and Sturm, K.: Airborne observations of the Eyjafjalla volcano ash cloud over Europe during air 
space closure in April and May 2010, Atmos. Chem. Phys., 11, 2245-2279, doi:10.5194/acp-11-2245-2011, 2011.

Seinfeld, J. H. and Pandis, S. P.: Atmospheric Chemistry and Physics - From Air Pollution to Climate Change (2nd Edition), John Wiley and Sons, p. 86, 2006.

Shaw, J. S., Allwine, K. J., Fritz, B. G., Rutz, F. C., Rishel, J. P., and Chapman, E. G.: An evaluation of the wind erosion module in DUSTRAN, Atmos. Environ., 42, 1907-1921, doi:10.1016/j.atmosenv.2007.11.022, 2008.

Skamarock, W. C., Klemp, J. B., Dudhia, J., Gill, D. O., Barker, D. M., Duda, M., Huang, X.-Y., Wang, W., and Powers, J. G.: A Description of the Advaced Research WRF Version 3, NCAR Technical note NCAR/TN-475+STR, 2008.

Stohl, A.:, On the pathways and timescales of intercontinental air pollution transport, J. Geophys. Res., 107, 4684, doi:10.1029/2001JD001396, 2002.

Stohl, A.: Characteristics of atmospheric transport into the Arctic troposphere, J. Geophys. Res., 111, D11306, doi:10.1029/2005JD006888, 2006.

Stohl, A., Eckhardt, S., Forster, C., James, P., Spichtinger, N., and Seibert, P.: A replacement for simple back trajectory calculations in the interpretation of atmospheric trace substance measurements, Atmos. Environ., 36, 4635-4648, 2002.

Stohl, A., Forster, C., Frank, A., Seibert, P., and Wotawa, G.: Technical note: The Lagrangian particle dispersion model FLEXPART version 6.2, Atmos. Chem. Phys., 5, 2461-2474, doi:10.5194/acp-5-2461-2005, 2005.

Stuart, A.: On a Black Sand from South-East Iceland, Geol. Mag., 64, 540-545, doi:10.1017/S0016756800103899, 1927.
Taylor, J. P., Glew, M. D., Coakley, J. A., Tahnk, W. R., Platnick, S., Hobbs, P. V., and Ferek, R. J.: Effects of Aerosols on the Radiative Properties of Clouds, J. Atmos. Sci., 57, 2656-2670, 2000.

Thorsteinsson, T., Gísladóttir, G., Bullard, J., and McTainsh, G.: Dust storm contributions to airborne particulate matter in Reykjavík, Iceland, Atmos. Environ., 45, 5924-5933, doi:10.1016/j.atmosenv.2011.05.023, 2011.

Warneke, C., Bahreini, R., Brioude, J., Brock, C. A., de Gouw, J. A., Fahey, D. W., Froyd, K. D., Holloway, J. S., Middlebrook, A., Miller, L., Montzka, S., Murphy, D. M., Peischl, J., Ryerson, T. B., Schwarz, J. P., Spackman, J. R., and Veres, P.: Biomass burning in Siberia and Kazakhstan as an important source for haze over the Alaskan Arctic in April 2008, Geophys. Res. Lett., 36, L02813, doi:10.1029/2008GL036194, 2009.

Zaveri, R. A. and Peters, L. K.: A new lumped structure photochemical mechanism for large-scale applications, J. Geophys. Res., 104, 30387-30415, doi:10.1029/1999JD900876, 1999.

Zaveri, R. A., Easter, R. C., Fast, J. D., and Peters, L. K.: Model for Simulating Aerosol Interactions and Chemistry (MOSAIC), J. Geophys. Res., 113, D13204, doi:10.1029/2007JD008792, 2008.

Zhao, C., Liu, X., Leung, L. R., Johnson, B., McFarlane, S. A., Gustafson Jr., W. I., Fast, J. D., and Easter, R.: The spatial distribution of mineral dust and its shortwave radiative forcing over North Africa: modeling sensitivities to dust emissions and aerosol size treatments, Atmos. Chem. Phys., 10, 8821-8838, doi:10.5194/acp-10-8821-2010, 2010. 